\title{
Preference and Performance of the Pine-Tree Lappet Dendrolimus pini on Various Pine Species
}

\author{
Adrian Lukowski ${ }^{1,2, * D}$, Marian J. Giertych ${ }^{1,3} \mathbb{D}$, Dawid Adamczyk ${ }^{1}$, Ewa Mąderek ${ }^{1}$ and Piotr Karolewski $^{1}$ \\ 1 Institute of Dendrology, Polish Academy of Sciences, Parkowa 5, 62-035 Kórnik, Poland; \\ giertych@man.poznan.pl (M.J.G.); dawidadamczyk.mog@gmail.com (D.A.); \\ emaderek@man.poznan.pl (E.M.); pkarolew@man.poznan.pl (P.K.) \\ 2 Faculty of Forestry and Wood Technology, Poznań University of Life Sciences, Wojska Polskiego 71c, \\ 60-625 Poznań, Poland \\ 3 Faculty of Biological Sciences, University of Zielona Góra, Prof. Z. Szafrana 1, 65-516 Zielona Góra, Poland \\ * Correspondence: adrian.lukowski@gmail.com
}

Citation: Łukowski, A.; Giertych, M.J.; Adamczyk, D.; Mąderek, E.; Karolewski, P. Preference and Performance of the Pine-Tree Lappet Dendrolimus pini on Various Pine Species. Forests 2021, 12, 1261. https://doi.org/10.3390/f12091261

Academic Editor: Luisa Ghelardini

Received: 20 July 2021

Accepted: 13 September 2021

Published: 16 September 2021

Publisher's Note: MDPI stays neutral with regard to jurisdictional claims in published maps and institutional affiliations.

Copyright: (c) 2021 by the authors. Licensee MDPI, Basel, Switzerland. This article is an open access article distributed under the terms and conditions of the Creative Commons Attribution (CC BY) license (https:// creativecommons.org/licenses/by/ $4.0 /)$.

\begin{abstract}
Global commercial and recreational transport may lead to the unintentional invasion of insect species, which in turn may pose a threat to native organisms. In this study, we aimed to assess whether the economically important pest of Pinus sylvestris L., moth Dendrolimus pini L. (DP), is able to feed on nine other pine species, and how this will affect its survival, performance, growth, and development. We carried out food choice tests and a no-choice laboratory feeding experiment. We found that this insect mostly preferred its prime host, but also Pinus cembra L., Pinus contorta Douglas ex Loudon, Pinus nigra J.F.Arnold, and Pinus ponderosa Douglas ex C.Lawson. The performance test revealed a host-specific response of DP to the host plant. This response was manifested in a large variation in body mass as well as in a decrease or increase in life-history traits, such as fecundity, and wing morphology parameters. However, the larvae's choice of particular hosts corresponded to the results of the performance test. Larvae more willingly selected food allowing better results in their performance. Larvae achieved better values of growth and development when fed on European and North American pine species or on species with two- and three-needle fascicles. In addition, attractants and repellents in needles of different pine species were chemically analyzed. Variations in the secondary metabolite composition as well as the specific leaf area of different pine species effectively explained the results found in the insects, but the content of sugars and nitrogen remains to be elucidated. We speculate that DP poses a serious threat to large areas of pine forests, if transferred, as it can survive and develop on many economically important tree species in North America and Europe.
\end{abstract}

Keywords: alien insect species; body mass; Dendrolimus pini; folivorous insect; instar; Lepidoptera; Pinus; potentially invasive pest; Scots pine; survival

\section{Introduction}

Herbivores use various parts of host plants to obtain the required nutrients for development and reproduction [1-3]. Plants improve their defense strategies to counteract feeding, especially by enhancement of the leaf chemical defense [4-7]. The quality of plants has a significant influence on the survival and development of larvae and the fecundity of adults [8,9], and thus is a key factor in determining the fitness of the herbivorous insect population and its increases and outbreaks [8,10]. Ingesting high-quality food improves larval performance [11] and, as a consequence, enhances survival $[12,13]$ and adult specimen reproduction $[8,14,15]$.

Invasive insects are the most disruptive species [16-18], causing various ecological $[19,20]$, social $[17,21,22]$, and economic problems [23-25]. Biological invasions are particularly threatening for countries with high forest cover $[26,27]$; therefore, it is important to protect forests from consequences through ongoing monitoring [28]. The risk of 
introducing a new insect species is positively correlated with the trade of forest products in environmental conditions that it prefers, i.e., areas with a favorable climate and suitable host plants [23]. Basic tools that can be used first are predictive studies evaluating the potential threat posed by potentially invasive insects [29,30]. A good prediction model of the potential distribution should also take into account potential host plants, the inclusion of which should be preceded by the examination of the possibility of accepting such hosts [31,32].

In Europe, the pine-tree lappet Dendrolimus pini (DP; Lepidoptera: Lasiocampidae) is a pest of great economic importance [33-35]. The natural range of the pine-tree lappet in Europe, which is known to be oligophagous on pines, follows that of its primary host, Pinus sylvestris [27]. The larvae of DP feed gregariously on needles of mature trees, usually $<20$ years old [36]. Females lay ca. 250 eggs in total July-August, and the first instars of larvae feed before the end of October, overwinter in forest litter, and resume feeding in early spring on one-year-old needles of P. sylvestris [36-38].

There is a lack of research with regard to other pine species-related food preferences. Recently, in Croatia the total defoliation of Aleppo pine Pinus halepensis Mill. stands has been observed. Although Aleppo pine is not its primary host, the larvae accepted it $[39,40]$. As an oligophagous species, DP consumes probably a limited number of plant species; thus, theoretically, intraspecific temporal and spatial variability in food quality should be important for this species. It can be expected that larval preferences and performances could be influenced by the needle chemistry of other species, as with other oligophagous serious pests of Scots pine Lymantria monacha L. [32].

In order to compare the food quality, we bred DP larvae on different host plantsvarious Pinus sp. L. species. We selected the plant species for research, taking into account their widest possible geographical distribution, morphological variability, and finally their high economic/ornamental importance. European countries are the main trading partner with Asian and North American ones, meaning that native European insects have a greater chance to be transported and become established in these areas [26]. For instance, findings for L. monacha show that this moth has the potential to be accidentally introduced via trade into U.S. areas due to the fact that many North American plants (coniferous and deciduous) are suitable hosts [32], and that the larvae can survive longer without food than previously assumed [41].

The nutritional quality of host plant foliage varies naturally among different species $[25,42,43]$. The variation in host plant quality can be determined by herbivores' specific food preferences and behaviors [2,32,43]. The reaction of insects to the change of the host is usually difficult to predict. The food demand during the development of DP larvae is initially low, but from the fourth instar, it increases rapidly [34]. Thus, it can be assumed that the coincidence in time of high food demand with the starvation period during transportation conditions may cause DP to accept other hosts in order to survive [44]. Using new host plants may cause reduced mass and growth parameters in insects, and extend the development time of the larvae, which will result in their increased mortality. On the other hand, native plant specimens are characterized by well-developed mechanisms of defense against insect pests, which have not yet been acquired by species that become new food for insects $[20,25]$. This may trigger their potential as destructive, invasive pests.

Due to their body size and mass, DP in a natural way do not spread over long distances [27]. This may seem to rule out the potential invasiveness of DP. However, this feature does not determine whether or not the species may be invasive. For example, one of the most famous invasive species, Lymantria dispar L., also spreads naturally only several hundred meters [45]. DP has many features of a potentially important invasive and troublesome species. In Poland, severe outbreaks usually take place every 4 to 16 years [37,46], but from the beginning of the 2000s, a significant reduction in the interval between outbreaks has been observed, as now it is from 2 to 3 years [33]. The most recent outbreak covered an area exceeding 130,000 ha in 2013 [47]. Outbreaks or even annual severe defoliation could result 
in tree mortality [48]. All developmental stages could easily use anthropogenic vectors, as they are pests closely related to pine, which is the most popular forest resource in Europe. Recently, we also found that the maximum lifespan of the starved L1 larvae was more than a week, but L3 larvae survived almost a month [44]. Recovery on their native host plant after starvation, which was supposed to simulate the conditions of long transport, was possible. The above studies confirm that this species can survive long periods of migration to almost anywhere in the world using a variety of vectors.

The aim of the research was to check whether DP larvae have preferences for alternative food, i.e., for various species of the pine genus Pinus sp., and how this will affect their survival, as well as their performance, growth, and development parameters. The assessment of the possibilities of feeding on other host plants is essential for understanding the interaction between DP larvae and their primal and potential hosts. Accordingly, in this study, we propose the following hypotheses, the verification of which formed our detailed objectives: (1) larvae of DP prefer the primal host plant; (2) the specimens of DP fed with pine species other than the basic food plant are characterized by a lower survival rate, growth, development, and morphological parameters; (3) DP achieves higher values of growth, development, and morphological parameters when they are fed on European pine species than on Asian or North American, or (4) pine species with two needle-fascicles rather than three or five needles; (5) chemical and physical defensive features of the needles of different pine species significantly influence larval performance.

\section{Materials and Methods}

\subsection{Study Species Characteristics}

We used eggs, all larval stages, pupae, and adult insects of the pine-tree lappet Dendrolimus pini L. (DP). The overwintering larvae were derived from Scots pine Pinus sylvestris L. stands litter in the Sarbia Forest District, State Forests, in Poland $\left(52.9445^{\circ} \mathrm{N}\right.$, $16.7699^{\circ} \mathrm{E}$ ). After collecting approximately 3000 larvae (end of February 2020), they were transported to the laboratory, where they were bred in six boxes $(25 \mathrm{~L})$. During the first few days of breeding, the process of the larvae emerging from winter diapause was observed, and then the dynamics of the activity of endoparasites and entomopathogenic fungi were noted. Any dead larvae or those showing disease symptoms were immediately removed from the boxes, and the tools were disinfected. After approximately 3 weeks, when the above-mentioned processes ended and the larvae began to chew intensively, our experiments began (10 April 2020). All experiments were carried out with the protection of human health due to strong allergens in larvae hairs [49]. Due to the high damage risks in neighboring pine stands, all larvae and adult insects were killed at the end of the experiment by transferring them to a deep freezer for one week.

In 2017, the plots were prepared on an open post-agricultural area free of weeds. The top layer of post-agricultural soil was mixed with acid peat and forest soil (collected in a mature oak/pine forest). We also added the slow-release NPK fertilizer $\left(2 \mathrm{~kg} \mathrm{~m}^{-3}\right.$ of added mixture of acid peat and forest soil). Next, over 100 similarly sized young trees (3-4 years old) per 10 pine species (Table 1) were planted and later employed to feed the larvae according to the established schedule (see subsequent section). Throughout the growing seasons, the trees were cared for and watered as needed. On the day of food exchange, we supplied fresh shoots with one-year-old needles, which we obtained from a randomly selected tree. We always collected plant material from different trees to avoid the effects of induced plant defense that may be stimulated during successive shoot/needle collection. 
Table 1. Pine species that were selected for this study.

\begin{tabular}{rrccc}
\hline & Scientific Name & Common Name & Place of Origin & Number of Needles in Fascicles \\
\hline 1. & Pinus armandii Franch. & Chinese white pine Eastern & Eastern Asia & Five \\
2. & Pinus cembra L. & Etone pine & Europe & Five \\
3. & Pinus contorta Dougl. ex Loud. & Lodgepole pine & North America & Two \\
4. & Pinus koraiensis Siebold and Zucc. & Korean pine & Eastern Asia & Five \\
5. & Pinus nigra Arn. & Europe & Two & Five \\
6. & Pinus peuce Griseb. & Macedonian pine & Europe & Three \\
7. & Pinus ponderosa & Ponderosa pine & North America & Five \\
8. & Douglas ex C. Lawson & White pine & North America & Two \\
9. & Pinus strobus L. & Scots pine & Europe & Five \\
10. & Pinus wallichiana A.B. Jacks & Himalayan pine & Eastern Asia & \\
\hline
\end{tabular}

\subsection{Study Design \\ 2.2.1. Food Choice}

Food choice by larvae was studied in mid-April 2020 using multi-choice (10 options) and dual-choice experiments. In the multi-choice experiment, we used flat polystyrene boxes ( $\mathrm{L} \times \mathrm{W} \times \mathrm{H}$ of $270 \times 270 \times 100 \mathrm{~mm}, \sim 7.3 \mathrm{~L}$, as in our other study [50]), but for the dual choice experiment we used plastic Petri dishes $(\varnothing 14 \mathrm{~cm})$. To standardize the choice conditions, plant materials in each box were inserted approximately $36^{\circ}$ apart near the walls of the box (the center of the container was free); in Petri dishes, they were placed opposite each other (at the walls of the dish), and the needles were cut into $1 \mathrm{~cm}$ pieces (due to different sizes of the tested needles). We used needles from randomly selected individuals of different pine species, and when cutting needles, we used separate scalpels and disposable gloves to keep odors free. Using soft tweezers, we randomly selected $(n=150)$ freshly molted larvae (c.a. $12 \mathrm{~h}$ earlier) from our big rearing containers and placed them in empty $20 \mathrm{~L}$ containers without food (for $4 \mathrm{~h}$ ). Afterward, 50 pieces of each studied species (Table 1) were stacked in small piles in each box of the all options experiment $5 \mathrm{~min}$ before placing the larvae in the central part of the boxes. The order in which the needles of different species were arranged next to each other varied. All of the prepared boxes containing the larvae were placed under constant conditions $\left(23{ }^{\circ} \mathrm{C}\right.$; RH $60 \%$; LED lighting similar to natural), and after $2 \mathrm{~h}$, the chosen species or no choice was noted based on the place that larvae started to chew.

In a similar way and under the given conditions, we prepared Petri dishes for the dual-choice experiment. In this part of the food choice experiment, we randomly selected freshly molted larvae $(n=360$, i.e., 40 larvae $\times 9$ pine species other than Scots pine) from our big rearing containers and starved them for $4 \mathrm{~h}$. Afterward, 10 pieces of Scots pine needle (control) and one of the studied species (Table 1) were placed in the appropriate dishes $5 \mathrm{~min}$ before placing the larvae in the central part of the dish. After $2 \mathrm{~h}$, the chosen species or no choice was noted based on the place that larvae started to chew.

\subsubsection{Performance Test}

We carried out a no-choice (one option) laboratory feeding experiment. On 10 April 2020, the experiment began. All larvae that completed the molting process the previous night (easily identified by the lighter body and hair color) were selected from the containers and placed into a larger container (containing larvae from various boxes). From this group of rearing larvae, we randomly selected 200 larvae from all available larvae $(n=20$ larvae $\times 10$ pine species treatments). Each larva was weighed to determine the initial larval mass before being placed in the Petri dish. Therefore, we were sure that the larvae were empty of feces and hungry, ready to start feeding again. The analytical balance Radwag (AS82/220.R2) with an accuracy of $0.01 \mathrm{mg}$ was used for weighing throughout the study. We placed the larvae individually into separate dishes $(\varnothing 14 \mathrm{~cm})$ with one-year-old needles of the right species. The larvae were stored in conditions as close to natural as possible, i.e., at a temperature of $23{ }^{\circ} \mathrm{C}$, a relative humidity of $60 \%$, and LED lamps were also used to approximate the light conditions. The light emitted per day lasted $16 \mathrm{~h}$. For 
each dish, needles were replaced by a new one, and larval mass was measured twice a week. Approximately double the requirement of food for one larva was provided for each larva. Uneaten needle residues and feces were weighed after they were dried in a forced air oven at $65^{\circ} \mathrm{C}$ for a minimum of $72 \mathrm{~h}$ (ULE $600 \mathrm{Memmert} \mathrm{GmbH}+\mathrm{Co}$. KG, Schwabach, Germany). Larvae mortality was monitored every day at 9.00 a.m. In order not to expose the individuals to additional stress, the dishes were not touched; however, if the observations indicated death, the container was gently opened to touch the larvae with tweezers to ascertain death. To estimate the fresh/dry mass ratio (for each host species treatment and date during the feeding period), the fresh mass of a needle was compared with its dry mass based on 10 samples collected from the needles of each pine species ( $n=3$ samples per species in each day of food replacement).

To determine insect performance, we used various parameters of growth and development. We determined maximal larval, pupal, cocoon, and adult masses. Moreover, we determined potential fecundity and various parameters of wings (described below). In addition, we used the following parameters: duration of development (DD; day), pupal period (PP; day), total food eaten (TFE; g dry mass), consumption index (CI; $\mathrm{g} \mathrm{g}^{-1} \mathrm{day}^{-1}$ ), relative growth rate ( $R G R ; \mathrm{g} \mathrm{g}^{-1} \mathrm{day}^{-1}$ ), approximate digestibility (AD; \%), efficiency of conversion of ingested food (ECI; $\mathrm{g} \mathrm{g}^{-1} \times 100 \%$ ), and efficiency with which digested food was converted to body substance (ECD; \%).

The parameter DD was then recorded, i.e., the period from the beginning of the experiment until the individual reached the pupal state (days). The cocoons built by the larvae were cut open and removed, and the pupae were weighed. When determining the mass of the cocoons, the mass of the last molt that was in these cocoons was not taken into account. In addition, we noted PP, the time from pupation to the emergence of an adult. After measuring the mass, each pupa was placed in a $125 \mathrm{~mL}$ vessel, into which a fragment of a woody shoot was inserted in order to create an optimal place for the freshly emerged adult to spread its wings. After the emerging of an adult insect was detected, anesthesia with ethyl acetate vapor was applied to determine the sex and body mass. It was then killed by quick freeze. In addition, wings were cut and removed from the body, and the length, width, and area of each forewing and hindwing was measured using a high-resolution scanner (800 dpi) and the WinFolia 2004 software (Regent Instruments Inc., Québec, Canada). Wing length and width were defined as the longest and widest possible section on each wing lying at right angles to each other. Total food eaten was calculated by summing the estimated dry mass eaten by the larvae from the start to the end of the experiment (i.e., 60 days). We determined CI based on the formula CI $=$ TFE/DD $\times M$, where $M$ is the fresh mass of a larva during the feeding period. We assessed RGR using the formula $R G R=\left(M_{m}-M_{0}\right) /\left(D D \times M_{0}\right)$, where $M_{0}$ and $M_{m}$ are the initial and maximal larval masses, respectively. Based on the larval mass and TFE, we also defined the ECI using the formula $\mathrm{ECI}=\left(\left(\mathrm{M}_{\mathrm{m}}-\mathrm{M}_{0}\right) / \mathrm{TFE}\right) \times 100 \%$. We calculated AD using the formula $\mathrm{AD}=(\mathrm{TFE}-\mathrm{F}) /(\mathrm{TFE}) \times 100 \%$, where $\mathrm{F}$ is the total mass of feces. ECD was calculated by $\mathrm{ECD}=\left(\left(\mathrm{M}_{\mathrm{m}}-\mathrm{M}_{0}\right) /(\mathrm{TFE}-\mathrm{F})\right) \times 100 \%$. Preliminary rearing carried out in the earlier years showed the effectiveness of these methods. More details concerning the methods and parameters that we used in this study can be found in the literature [25,51-53].

Moreover, in order to determine the potential fecundity of the females, the ovaries were isolated approximately $24 \mathrm{~h}$ after freezing. During ovarian isolation, each female was placed on her back and attached with entomological pins to the Sylgard elastomer in a Petri dish filled with Ringer's solution. Each pinned insect was cut along the ventral side of the abdomen with microsurgical scissors. Fat bodies and Malpighi coils were removed from the abdomen using microtweezers. The ovary was also removed to expose and isolate it. Ovaries were stained with $0.5 \%$ Evans Blue in saline. Potential fecundity was assessed as the total number of pre-vitellogenic and vitellogenic oocytes in the ovaries (No. eggs). 


\subsection{Chemical Analysis and Specific Leaf Area Determination}

We chemically analyzed attractants and repellents in the one-year-old needles of different pine species ( $n=8$ samples $\times 10$ pine species $\times 2$ months) over two consecutive months (in mid-April and mid-May). We analyzed the basic chemical composition of needles, including water content; carbon and nitrogen concentrations; total non-structural carbohydrates; and defensive compounds, such as condensed tannins, soluble phenolics, and total terpenoids content. Plant material was collected randomly from different individuals growing together with individuals from which shoots had been collected for the choice and performance test to avoid the additional influence of the cutting of tissues.

Nitrogen and carbon contents (\% d.m.) were determined using an Elemental Combustion System CHNS-O 4010 analyzer (Costech Instruments, Pioltello, Italy). Total nonstructural carbohydrates (TNC; i.e., soluble carbohydrates and starch) were determined as described by Hansen and Møller [54] and Haissig and Dickson [55]. Soluble carbohydrates were assayed in methanol-chloroform-water extracts $(\lambda=625 \mathrm{~nm})$, and TNC results were expressed as \% d.m. Total soluble phenols (TPh) and condensed tannins were analyzed in dried leaf tissue $\left(40{ }^{\circ} \mathrm{C}\right.$ for tannins and $65{ }^{\circ} \mathrm{C}$ for other phenols) ground in a Mikro-Feinmühle-Culatti mill (IKA Labortechnik, Staufen im Breisgau, Germany). The phenolic compound content was measured calorimetrically $(\lambda=660 \mathrm{~nm})$ using Folin and Ciocalteu's Phenol Reagent (SIGMA F-9252) and following the method of Johnson and Schaal [56], as modified by Singleton and Rossi [57]. Chlorogenic acid was the standard used in these assays, and the results were expressed in terms of $\mu \mathrm{M}$ of chlorogenic acid $\mathrm{g}^{-1}$ dry mass (d.m.). Condensed (catechol) tannins, after extraction with absolute methanol, were determined colorimetrically $(\lambda=500 \mathrm{~nm})$ using a color reaction with vanillin in an acid medium [58]. These results were converted to $\mu \mathrm{M}$ catechin $\mathrm{g}^{-1} \mathrm{~d}$.m. The total terpenoid content (TT) was determined using linalool as the standard reagent using the method described by Ghorai et al. [59] with such a modification that the material was dried in the air for approximately a week. The absorbance was measured at $538 \mathrm{~nm}$, and the results were expressed as milligrams of linalool equivalents per gram of dried sample (mg linalool $\mathrm{g}^{-1}$ d.m.). Absorbance (terpenoids, tannins, phenols, and carbohydrates) was determined with a spectrophotometer (UV-1700 Visible Spectrophotometer; PharmaSpec, Shimadzu, Japan).

At the same time, undamaged needles were also collected for the assessment of specific leaf area (SLA; $\mathrm{cm}^{2} \mathrm{~g}^{-1}$ d.m.) [60,61]. Each needle sample was weighed, scanned (software: WinSeedle 2004, Regent Instruments Inc., Quebec, QC, Canada), dried $\left(65^{\circ} \mathrm{C}\right)$, and re-weighed. Each sample for SLA analysis was composed of 5-10 needles per sample.

\subsection{Statistical Analysis}

Data from the food choice tests were analyzed in 10-option and two-option experiments. It was assumed that the larvae that had not selected food would be excluded from further analysis. The $\chi^{2}$ test was used to analyze the probability of choosing pine species. We calculated the results of larvae choosing needles of specific pine species relative to the total number of larvae that had chosen food. These results were then analyzed by the $\chi^{2}$ test statistics to compare two probabilities with independent random samples. We hypothesized that differences in probability between species treatments would be zero as this is the general assumption. Survival analysis (the log-rank test) was applied to determine the differences in survival of the larvae between treatments over time while preparing the Kaplan-Meier survival curves needed to interpret the results of the analyses.

Data expressed as percentages were transformed to meet linear model assumptions using a formula proposed by Bliss [62]. Before starting the statistical analysis of the results, each time, the initial assumptions of the tests used (Shapiro-Wilk test, Kolmogorov $\lambda$ test and Bartlett's test) were checked. The performed Shapiro-Wilk test indicated that data for $\mathrm{DD}$, fecundity, RGR, $\mathrm{AD}, \mathrm{ECI}$, and ECD were not normally distributed; therefore, they were transformed (logarithmic). The results were then checked with the Kolmogorov $\lambda$ concordance test, which proved that the data had a log normal distribution. Thus, 
transformed data were used when needed. Additionally, transformed data were used for nitrogen, starch, TPh, tannins, and SLA due to the log normal distribution.

We prepared the results in such a way that we first describe the analyses performed separately for each pine species the larvae were fed. For a more general experiment, we then grouped the pine species constituting food, according to the information in Table 1 , into groups related to the geographic origin of these pines (Po), and the number of needles in fascicles (Nn). For these data, we performed two independent analyses. We used twoway analysis of covariance (ANCOVA) statistical tests with the nested effect, where the covariant was the initial larval body mass. To compare the chemical composition of needles from different species over two consecutive months of plant material collection (April and May), nested analysis of variance (ANOVA) was also used. Both in ANCOVA and ANOVA, pine species were nested in the Po or Nn.

After the analysis, where it was possible and depending on the need, Tukey's or Dunnet's post hoc test was used $(\alpha=0.05)$. Additionally, a linear regression equation in the form of $f(y)=a x+b$ was performed to show the dependence of both sexes' wing areas and female fecundity on their body mass. The Pearson correlation matrix was also used, where the Pearson correlation coefficients for the wing parameters were calculated. The data on the figures were expressed as means with standard errors of the mean $( \pm S E)$. All calculations were performed using the JMP software (SAS Institute Inc., Cary, NC, USA).

\section{Results}

\subsection{Food Choice}

Only seven of 150 larvae in the multi-choice and 14 of the 360 in the dual-choice experiments did not make a choice during the study period. They usually stood in the same place they were placed and were not interested in food. Thus, they were not taken into account in the further statistical analyses. The results of $\chi^{2}$ tests in the multi-choice experiment, where each larva had the opportunity to choose from 10 different host plants, indicate that that the estimated probability differs significantly from the hypothesized values in some plant species treatments $\left(\chi^{2}=94.2727 ; p<0.0001\right.$; Figure 1$)$. The most frequently chosen species was P. sylvestris (30\%), and together with P. nigra and P. cembra, they constituted as much as $63 \%$ of all of the food selections made. The choice of a single remaining species did not exceed $8 \%$.

The $\chi^{2}$ tests showed that the estimated probability in the dual-choice experiment differed significantly from the hypothesized values in some plant species treatments. A significant difference was observed between $P$. sylvestris (control) and species such as P. armandii $\left(\chi^{2}=12.7368 ; p=0.0002\right)$, P. koraiensis $\left(\chi^{2}=16.0256 ; p<0.001\right)$, P. peuce $\left(\chi^{2}=5.7692 ; p=0.0163\right)$, P. strobus $\left(\chi^{2}=16.7368 ; p=0.0084\right)$, and P. wallichiana $\left(\chi^{2}=15.1579 ;\right.$ $p<0.001)$. This indicates that the larvae chose food preferentially; however, no substantial preference was found to species other than P. sylvestris (Figure 2). For other species, such as P. cembra $\left(\chi^{2}=0.0256 ; p=0.8728\right)$, P. contorta $\left(\chi^{2}=2.0769 ; p=0.1495\right)$, P. nigra $\left(\chi^{2}=0.4211\right.$; $p=0.5164)$, and P. ponderosa $\left(\chi^{2}=1.6842 ; p=0.1944\right)$, there was no significant difference in food choice.

\subsection{Survival and Performance Test}

The log-rank survival test showed that there were non-significant differences in survival between the larvae fed on needles of different pine species $\left(\chi^{2}=7.2868 ; p=0.6073\right)$, and the average mortality was $13.5 \%$. Although non-significant, the Kaplan-Meier survival curve analysis showed that the mortality during the experiment was slightly different in species treatments: in P. contorta-25\% (5/20); in P. armandii and P. peuce-20\% (4/20); in P. koraiensis, P. ponderosa, and P. sylvestris-15\% (3/20); in P. cembra-10\% (2/20); and in P. nigra, P. strobus, and P. wallichiana-5\% (1/20). Additionally, non-significant differences were found in the survival rates between the larvae fed on pine species with different places of origin (log-rank; $\chi^{2}=0,1528 ; p=0.9265$ ), as well as fed on pines species with different numbers of needles in fascicles (log-rank; $\chi^{2}=0.2108 ; p=0.8999$ ). 


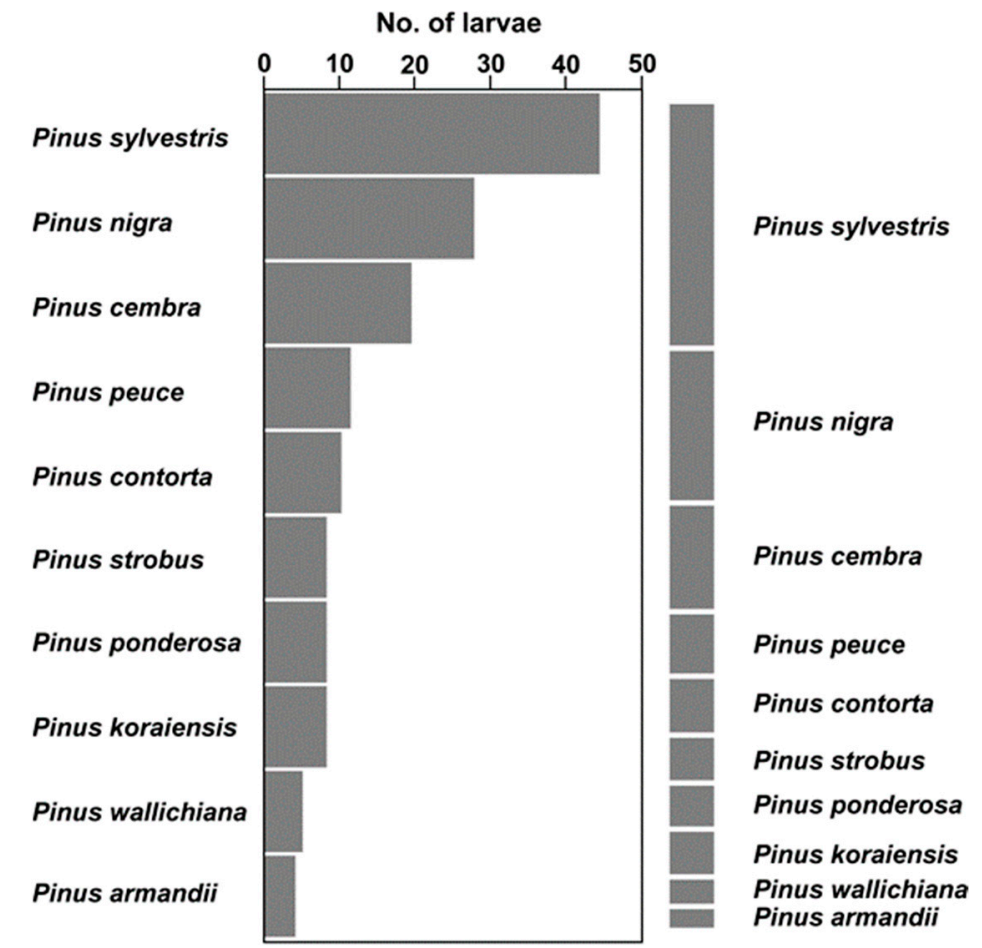

Figure 1. Bars showing the number of larvae, which chose specific food (left side), and a mosaic plot (right side) showing proportion of chosen pine species by the pine-tree lappet larvae (Dendrolimus pini L.) in the multi-choice (10 options) experiment.

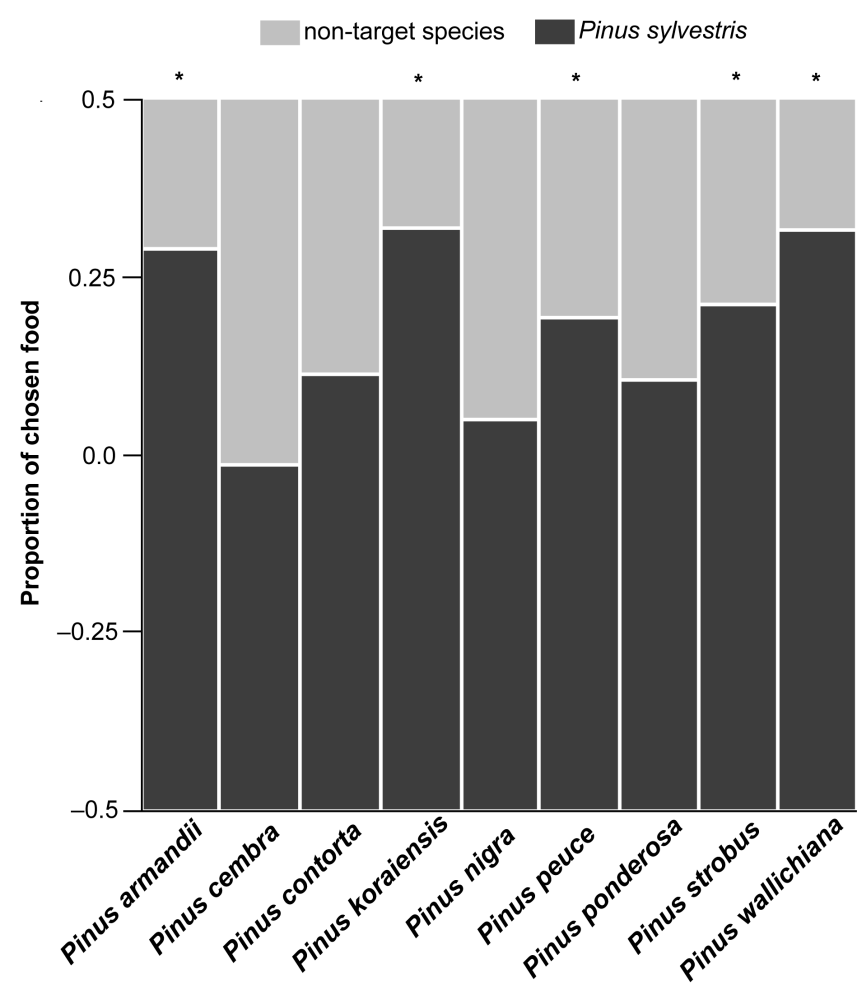

Figure 2. A mosaic plot showing proportion of chosen food by the pine-tree lappet larvae (Dendrolimus pini L.) in the dual-choice experiment with Pinus sylvestris L. and non-target species. Symbol * at the top of the bars indicate significant differences in the larval selection of the target and non-target host plants. 
The performance of DP larvae significantly depended on the experimental treatments, sex, and initial larval mass (Tables 2, A1 and A2). For the further analyses, data for 173 specimens were used. The mean initial mass of the larvae was $0.87 \mathrm{~g}( \pm 0.02 \mathrm{SE})$, and a significant impact of this covariant was usually noted. In addition, there was also a specific response of DP larvae to the applied different pine species (Tables A1 and A2). On the basis of Dunnett's tests, we found that in most pine species treatments the mean values of the masses and various parameters of growth and development were significantly lower than the value for the larvae fed with P. sylvestris, the primal host plant. However, in some pine species treatments ( $P$. contorta, P. nigra, and P. ponderosa), the achieved results were very similar to the result of larvae fed with $P$. sylvestris.

The larval, pupal, cocoon, and adult masses, as well as fecundity and wing areas showed different values depending on the pine origin treatment and on the number of needles in a fascicle treatment (Table 2). Food consisting of American and European pine species did not result in significant differences (except in cocoon masses), while Asian pine species reduced masses, fecundity, and wing area (Figure 3). The masses, fecundity and wing area of individuals fed with two- and three-needle pine species showed similar average values and were higher than those for individuals fed with five-needle pine species (Figure 4). In the case of these parameters, sex had an important influence on result variation, as the masses and wing areas of females were significantly higher than those of males (Table 2; Figures 3 and 4). The parameters achieved for the females were more varied, which also clearly showed the significant influence of the interactions (Po $\times S$, and $\mathrm{Nn} \times \mathrm{S}$ ), as shown in the figure. Due to the fact that all the morphological parameters of the wings of DP were closely correlated (Figure A1), to simplify the further detailed analysis of the tested treatments, we used only the data for the total wing area. Additionally, a linear regression was performed to show the dependence of the wing area of both sexes on body mass, as well as female fecundity on body mass. A positive correlation was found for female wing area $\left(r=0.9045 ; \mathrm{t}_{1 ; 78}=18.74 ; p<0.0001\right)$, and males $(r=0.7649$; $\left.\mathrm{t}_{1 ; 76}=11.01 ; p<0.0001\right)$, which can be represented by the following functions: female wing area $(y)=5.4754+6.2241 \times$ female adult mass $(x)$, and male wing area $(y)=6.4218+$ $10.0653 \times$ male adult mass $(x)$. Additionally, a positive correlation was found for fecundity $\left(r=0.8892 ; \mathrm{t}_{1 ; 80}=17.38 ; p<0.0001\right)$, which can be represented by the following function: fecundity $(y)=23.7805+122.4769 \times$ adult mass $(x)$. 


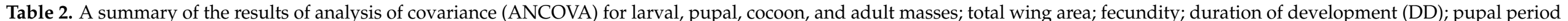

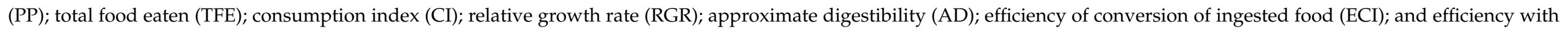

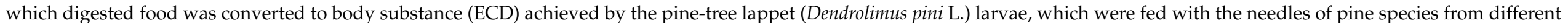

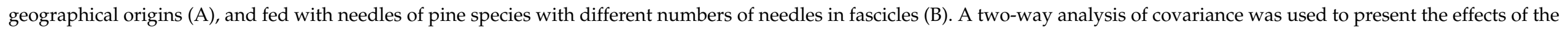

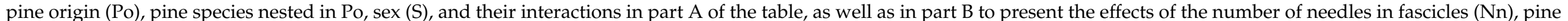

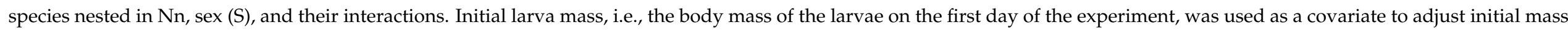
differences between insects. Statistically significant differences $p<0.05$ are marked in bold.

\begin{tabular}{|c|c|c|c|c|c|c|c|c|c|c|c|c|c|c|c|c|c|c|c|c|c|c|c|c|c|c|c|c|c|}
\hline \multicolumn{2}{|c|}{ A: Pine Origin } & \multicolumn{2}{|c|}{$\begin{array}{l}\text { Larval Mass } \\
\text { (g) }\end{array}$} & \multicolumn{2}{|c|}{$\begin{array}{l}\text { Pupal Mass } \\
\text { (g) }\end{array}$} & \multicolumn{2}{|c|}{$\begin{array}{c}\text { Cocoon Mass } \\
\text { (mg) }\end{array}$} & \multicolumn{2}{|c|}{$\begin{array}{l}\text { Adult Mass } \\
\text { (g) }\end{array}$} & \multicolumn{2}{|c|}{$\begin{array}{c}\text { Wings Area } \\
\left(\mathrm{cm}^{2}\right)\end{array}$} & \multicolumn{2}{|c|}{$\begin{array}{l}\text { Fecundity } \\
\text { (no. Eggs) }\end{array}$} & \multicolumn{2}{|c|}{$\begin{array}{l}\text { DD } \\
\text { (Day) }\end{array}$} & \multicolumn{2}{|c|}{$\begin{array}{c}\mathrm{PP} \\
\text { (Day) }\end{array}$} & \multicolumn{2}{|c|}{$\begin{array}{c}\text { TFE } \\
\text { (g d.m.) }\end{array}$} & \multicolumn{2}{|c|}{$\begin{array}{c}\mathrm{CI} \\
\left(\mathrm{g} \mathrm{g}^{-1} \text { Day }^{-1}\right)\end{array}$} & \multicolumn{2}{|c|}{$\begin{array}{c}\text { RGR } \\
\left(\mathrm{g} \mathrm{g}^{-1} \text { Day }^{-1}\right)\end{array}$} & \multicolumn{2}{|c|}{$\begin{array}{l}\mathrm{AD} \\
(\%)\end{array}$} & \multicolumn{2}{|c|}{$\begin{array}{l}\mathrm{ECI} \\
(\%)\end{array}$} & \multicolumn{2}{|c|}{$\begin{array}{c}\text { ECD } \\
(\%)\end{array}$} \\
\hline ANCOVA & df & $\mathrm{F}$ & $p$ & $\mathrm{~F}$ & $p$ & $\mathrm{~F}$ & $p$ & $\mathrm{~F}$ & $p$ & $\mathrm{~F}$ & $p$ & $F$ & $p$ & $\mathrm{~F}$ & $p$ & F & $p$ & F & $p$ & $F$ & $p$ & $F$ & $p$ & F & $p$ & $\mathbf{F}$ & $p$ & F & $p$ \\
\hline $\begin{array}{c}\text { Pine } \\
\text { origin } \\
(\mathrm{Po})\end{array}$ & 2 & 21.7357 & $<0.0001$ & 15.6451 & $<0.0001$ & 9.8975 & $<0.0001$ & 16.0361 & $<0.0001$ & 15.0088 & $<0.0001$ & 11.9165 & $<0.0001$ & 6.0039 & 0.0031 & 3.5827 & 0.0301 & 0.0017 & 0.9983 & 0.2910 & 0.7479 & 12.3612 & $<0.0001$ & 3.4169 & 0.0352 & 13.9226 & $<0.0001$ & 6.9901 & 0.0012 \\
\hline Sex (S) & 1 & 163.2014 & $<0.0001$ & 234.0973 & $<0.0001$ & 12.4169 & 0.0006 & 861.8713 & $<0.0001$ & 119.4269 & $<0.0001$ & & & 57.9123 & $<0.0001$ & 8.0228 & 0.0052 & 116.3617 & $<0.0001$ & 41.3346 & $<0.0001$ & 1.4211 & 0.2350 & 2.3150 & 0.1301 & 7.4947 & 0.0069 & 12.0833 & 0.0007 \\
\hline $\mathrm{Po} \times \mathrm{S}$ & 2 & 3.1348 & 0.0462 & 7.0945 & 0.0011 & 1.0654 & 0.3471 & 6.2480 & 0.0024 & 5.2590 & 0.0062 & & & 1.6033 & 0.2045 & 3.0142 & 0.0519 & 2.3347 & 0.1001 & 0.2399 & 0.7870 & 1.5459 & 0.2163 & 1.5808 & 0.2090 & 0.9614 & 0.3846 & 2.7967 & 0.0640 \\
\hline $\begin{array}{c}\text { Initial } \\
\text { larval } \\
\text { mass (cov) }\end{array}$ & 1 & 30.6088 & $<0.0001$ & 25.8380 & $<0.0001$ & 13.8404 & 0.0003 & 16.7247 & $<0.0001$ & 13.1889 & 0.0004 & 27.2014 & $<0.0001$ & 26.9124 & $<0.0001$ & 0.4294 & 0.5132 & 0.4661 & 0.4958 & 1.9916 & 0.1601 & 10.0633 & 0.0018 & 9.7943 & 0.0021 & 13.4641 & 0.0003 & 1.7707 & 0.1852 \\
\hline $\begin{array}{l}\text { B: Number } \\
\text { of needles } \\
\text { in fascicles }\end{array}$ & & Larva & 1 mass & $\begin{array}{r}\text { Pupal } \\
\quad(g\end{array}$ & mass & $\begin{array}{r}\text { Cocoo } \\
(\mathrm{n}\end{array}$ & $\begin{array}{l}n \text { mass } \\
\text { g) }\end{array}$ & $\begin{array}{r}\text { Adult } \\
\quad(g\end{array}$ & $\begin{array}{l}t \text { mass } \\
g)\end{array}$ & $\underset{\text { (cr }}{\text { Wing }}$ & $\begin{array}{l}\text { s area } \\
\left.n^{2}\right)\end{array}$ & $\begin{array}{l}\text { Fecu } \\
\text { (no. }\end{array}$ & $\begin{array}{l}\text { ndity } \\
\text { eggs) }\end{array}$ & $\begin{array}{c}\mathrm{D} \\
(\mathrm{d}\end{array}$ & $\begin{array}{l}\text { D } \\
\text { ay) }\end{array}$ & & $\begin{array}{l}\text { PP } \\
\text { lay) }\end{array}$ & $\begin{array}{r}\mathrm{Tl} \\
\mathrm{g} \mathrm{d}\end{array}$ & & $\left(\mathrm{g} \mathrm{g}^{-1}\right.$ & $\mathrm{day}^{-1}$ ) & $\left(\mathrm{g} \mathrm{g}^{-1}\right.$ & $\begin{array}{l}\text { GR } \\
\text { day }^{-1} \text { ) }\end{array}$ & & $\begin{array}{l}\mathrm{AD} \\
\%)\end{array}$ & $\begin{array}{l}\text { EC } \\
(\%\end{array}$ & CI & $\begin{array}{l}\mathrm{EC} \\
(\%\end{array}$ & \\
\hline ANCOVA & df & $\mathrm{F}$ & $p$ & $F$ & $p$ & $\mathrm{~F}$ & $p$ & $F$ & $p$ & $\mathrm{~F}$ & $p$ & $F$ & $p$ & $\mathrm{~F}$ & $p$ & $F$ & $p$ & F & $p$ & $F$ & $p$ & $F$ & $p$ & F & $p$ & $F$ & $p$ & $\mathrm{~F}$ & $p$ \\
\hline $\begin{array}{l}\text { Number of } \\
\text { needles } \\
(\mathrm{Nn})\end{array}$ & 2 & 45.0919 & $<0.0001$ & 33.1481 & $<0.0001$ & 8.1693 & 0.0004 & 38.9873 & $<0.0001$ & 26.0645 & $<0.0001$ & 32.8685 & $<0.0001$ & 8.3982 & 0.0003 & 6.6218 & 0.0017 & 20.9735 & $<0.0001$ & 6.6418 & 0.0017 & 20.4456 & $<0.0001$ & 5.5261 & 0.0048 & 6.7040 & 0.0016 & 5.7426 & 0.0039 \\
\hline $\begin{array}{c}\text { Pine } \\
\text { species } \\
{[\mathrm{Nn}]}\end{array}$ & 7 & 3.0357 & 0.0050 & 1.7341 & 0.1046 & 4.1680 & 0.0003 & 1.9163 & 0.0702 & 2.4977 & 0.0186 & 2.1141 & 0.0529 & 3.2732 & 0.0028 & 0.9980 & 0.4348 & 7.4770 & $<0.0001$ & 3.9222 & 0.0006 & 3.4258 & 0.0019 & 4.7192 & $<0.0001$ & 5.3125 & $<0.0001$ & 2.7553 & 0.0100 \\
\hline $\operatorname{Sex}(\mathrm{S})$ & 1 & 162.7075 & $<0.0001$ & 225.0700 & $<0.0001$ & 23.8280 & $<0.0001$ & 761.0352 & $<0.0001$ & 134.4132 & $<0.0001$ & & & 18.1564 & $<0.0001$ & 0.1903 & 0.6633 & 65.7105 & $<0.0001$ & 27.0208 & $<0.0001$ & 0.0089 & 0.9248 & 1.4248 & 0.2344 & 12.3074 & 0.0006 & 15.2884 & 0.0001 \\
\hline $\mathrm{Nn} \times \mathrm{S}$ & 2 & 7.6766 & 0.0007 & 10.3064 & $<0.0001$ & 5.7117 & 0.0040 & 14.0336 & $<0.0001$ & 8.8260 & 0.0002 & & & 6.7481 & 0.0015 & 5.6230 & 0.0044 & 4.2452 & 0.0160 & 0.0966 & 0.9080 & 4.0842 & 0.0186 & 0.1044 & 0.9010 & 2.9468 & 0.0554 & 2.3127 & 0.1023 \\
\hline
\end{tabular}



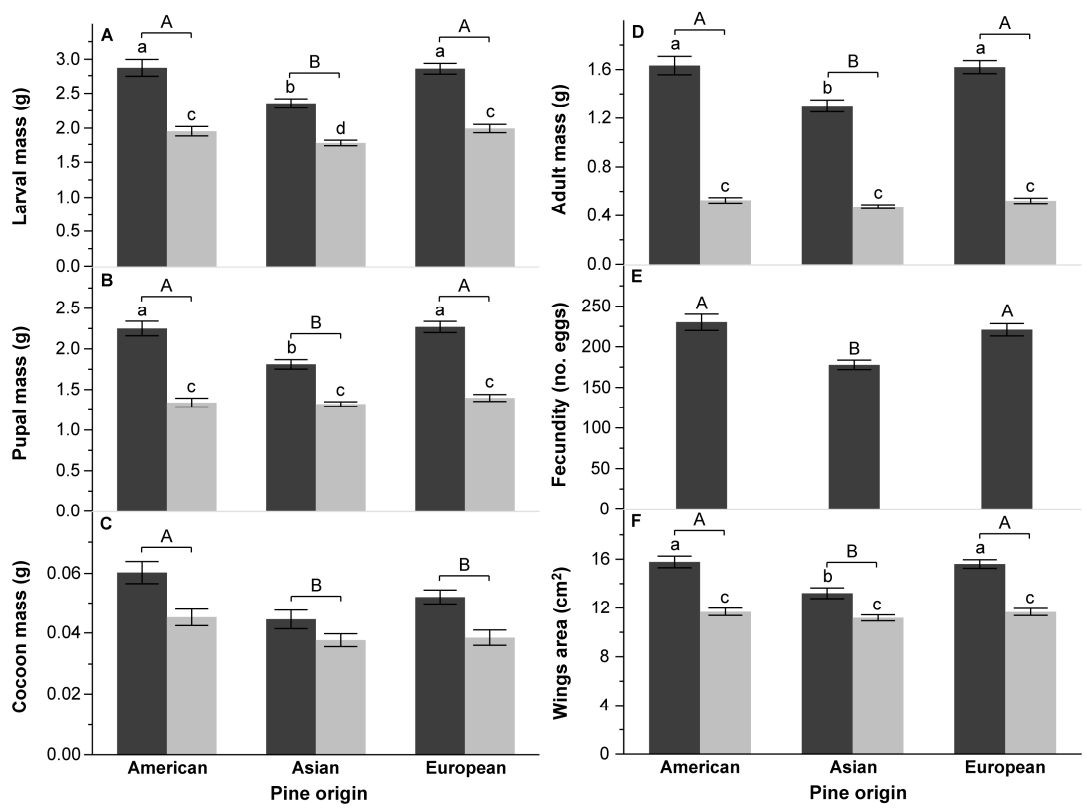

Figure 3. Mean values ( \pm SE) of maximal larval mass (A), pupal mass (B), cocoon mass (C), adult mass (D), fecundity (E), and wing area (F) achieved by the pine-tree lappet (Dendrolimus pini L.) larvae, which were fed with the needles of pines of different geographical origin (American, Asian, and European) classified by sex: females (dark) and males (light). Lowercase letters above the bars indicate result of Tukey's post hoc test $(\alpha=0.05)$ for pine origin $\times$ sex interaction, but uppercase letters indicate result for pine origin treatment (see also Table 1). Levels not connected by same letter are significantly different.
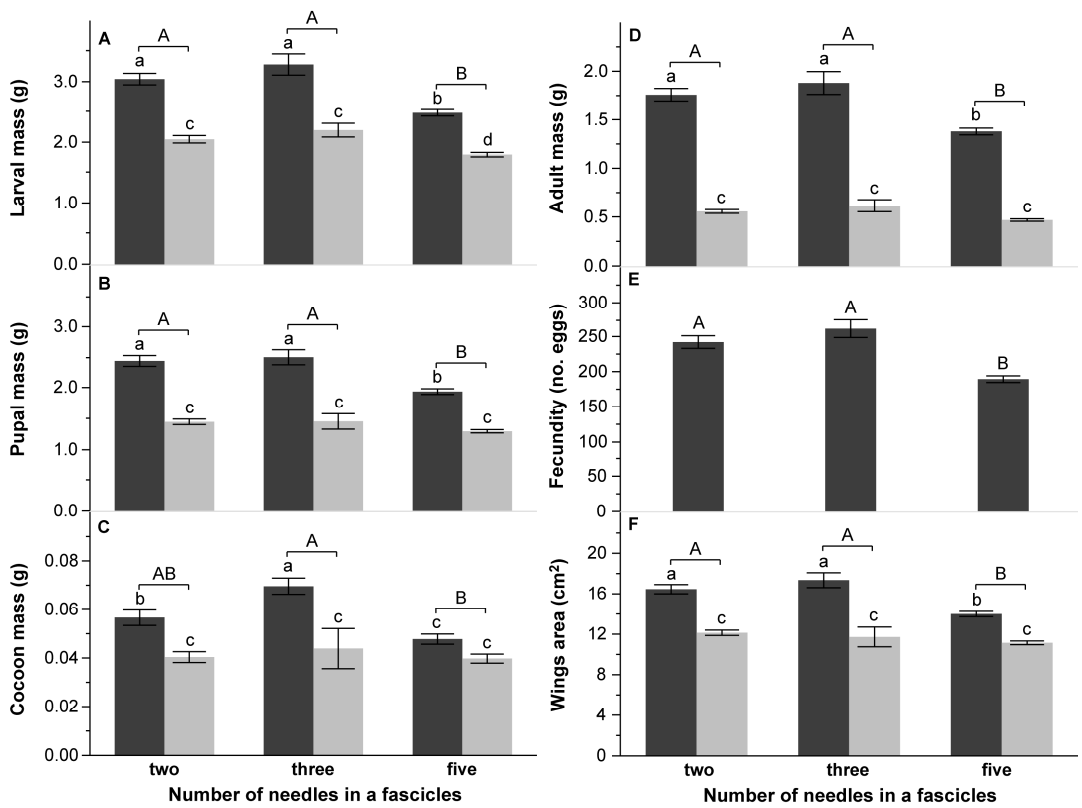

Figure 4. Mean values ( \pm SE) of maximal larval mass (A), pupal mass (B), cocoon mass (C), adult mass (D), fecundity (E), and wing area (F) achieved by the pine-tree lappet (Dendrolimus pini L.) larvae, which were fed with needles of pine species with different numbers of needles in fascicles (two, three, and five) classified by sex: females (dark) and males (light). Lowercase letters above the bars indicate result of Tukey's post hoc test $(\alpha=0.05)$ for interaction number of needles $\times$ month, and uppercase letters indicate result for number of needles in a fascicle treatment (see also Table 1). Levels not connected by same letter are significantly different. 
The established food treatments (the pine origin and the number of needles in fascicles) influenced DD or PP, which means that the larvae ingested different amounts of food (Table 2). The DD parameter was the highest in larvae fed with Asian pines and threeand five-needle pines (Figures $5 \mathrm{~A}$ and $6 \mathrm{~A}$ ), which indicates the prolongation of larval development when fed with this food. The PP parameter was the highest in larvae fed with European and American pines, and two-needle pines (Figures $5 \mathrm{~B}$ and $6 \mathrm{~B}$ ), which indicates the prolongation of pupal development when fed with this food. In general, the prolongation of DD was nullified by the acceleration of PP. Such regularity was also noticed for sex-males had a shorter DD, while females had a shorter PP-which more or less means that the hatching periods of both sexes fall on a similar time. A stronger but ambiguous result was the sex $\times$ number of needles in fascicles interaction.
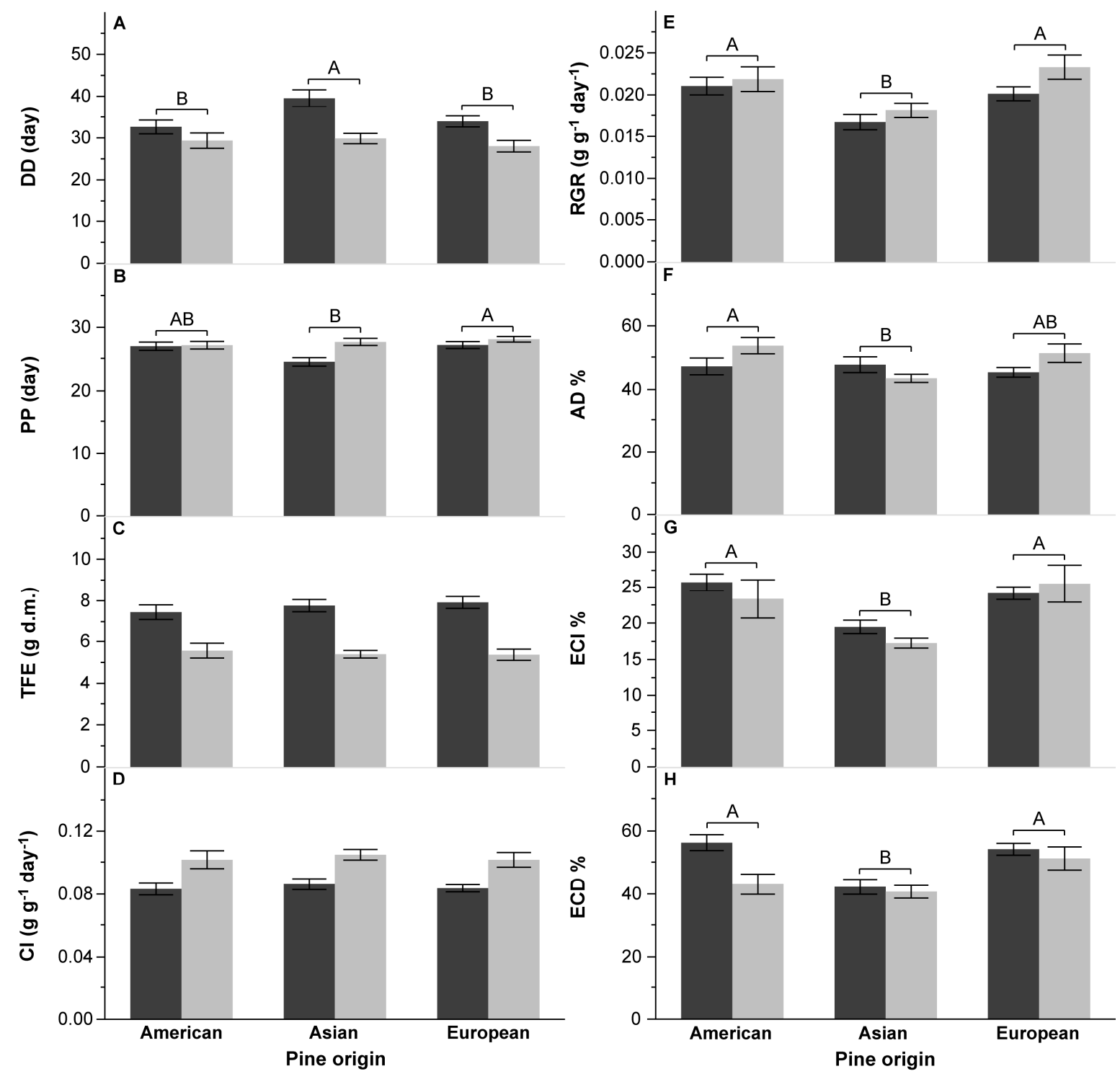

Figure 5. Mean values $( \pm \mathrm{SE})$ of duration of development (DD; (A)), pupal period (PP; (B)), total food eaten (TFE; (C)), consumption index (CI; (D)), relative growth rate (RGR; (E)), approximate digestibility (AD; $(\mathbf{F})$ ), efficiency of conversion of ingested food (ECI; (G)), and efficiency with which digested food was converted to body substance (ECD; (H)) achieved by the pine-tree lappet (Dendrolimus pini L.) larvae, which were fed with the needles of pines of different geographical origin (American, Asian, and European) classified by sex: females (dark) and males (light). Lowercase letters above the bars indicate result of Tukey's post hoc test $(\alpha=0.05)$ for interaction pine origin $\times$ sex, and uppercase letters indicate result for pine origin treatment (see also Table 1 ). Levels not connected by same letter are significantly different. 

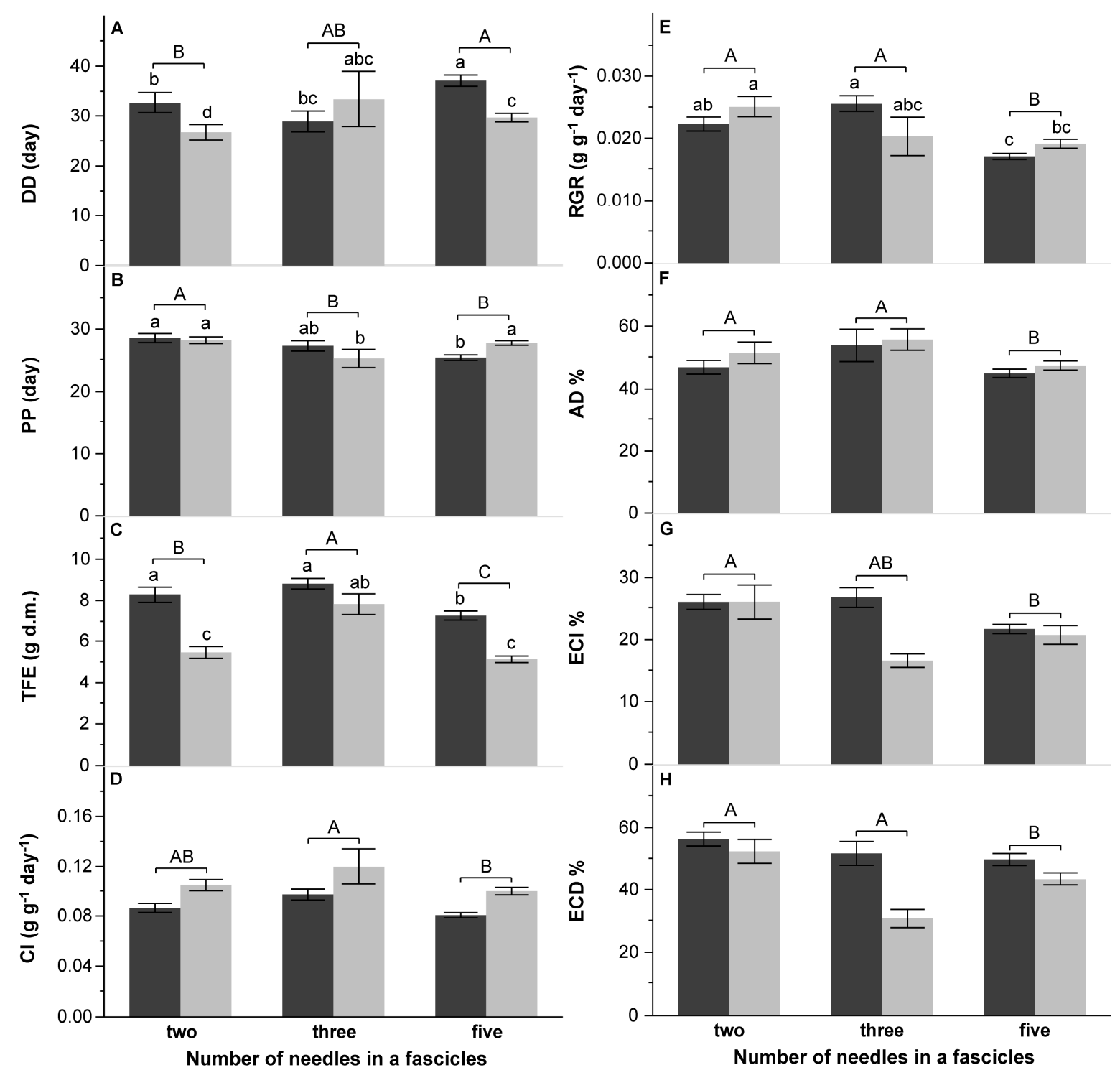

Figure 6. Mean values ( \pm SE) of DD (A), PP (B), TFE (C), CI (D), RGR (E), AD (F), ECI (G), and ECD (H) achieved by the pine-tree lappet (Dendrolimus pini L.) larvae, which were fed with needles of pine species with different numbers of needles in fascicles (two, three, and five) classified by sex: females (dark) and males (light). Lowercase letters above the bars indicate result of Tukey's post hoc test $(\alpha=0.05)$ for interaction number of needles $\times$ month, and uppercase letters indicate result for number of needles in a fascicle treatment (see also Table 1). Levels not connected by same letter are significantly different.

The number of needles in fascicles influenced TFE (total food eaten) and CI (consumption index), which means that the larvae ingested different amounts of food (Table 2 and Figure 6B), but this was not found for pine origin (Table 2 and Figure 5B). Larvae fed with five-needle pine species had the lowest TFE and CI parameters, while those fed with three-needle pines had the highest. Sex had a strong influence on TFE and CI, as the females ingested higher amounts of food than males. We also found a significant effect of the pine origin treatment and the number of needles in a fascicle treatment on RGR, AD, ECI, and ECD (Table 2). Levels from food consisting of American and European species did not differ significantly, while the Asian species caused a reduction (Figure 5F-H). Larvae fed with two-needle pine species showed similar average values of the studied parameters to larvae fed with three-needle pine species. However, the individuals receiving the five-needle species were characterized by significantly lower values. Thus, larvae feeding on Asian pine species and five-needle pine species gained body mass at a slower rate and were characterized by the worst $\mathrm{AD}, \mathrm{ECI}$, and ECD. It is worth noting that sex influenced 
the ECI and ECD, as in analyses for both (Table 2), females had higher values of these parameters.

\subsection{The Quality of Food}

We found a large impact of pine species (Table A3 in Appendix C), the number of needles in fascicle treatments, and the average influence of months of plant material collection during the insect feeding period (Table 3) on the quality of food. For most of the parameters studied, there was a significant interaction between these factors (excluding $\mathrm{N}$ and tannins). On the basis of Dunnett's tests, we found that in most pine species needles the content of metabolites was almost identical to that of $P$. sylvestris, the primal host plant. Only in two pine species treatments (P. armandii and P. peuce), the quality of food was clearly worse than that of $P$. sylvestris. We found an influence of pine origin on the content of substances that were favorable for insect development (nitrogen, starch, and TNC), the plant defense compound content (TPh, tannins, TT), as well as SLA values, which can represent the general mechanical defense of needles (Table 3 and Figure 7). At the same time, we found a large impact of the number of needles in fascicles on all food quality traits tested, except TT (Table 3 and Figure 8). American pines were characterized by a higher content of nitrogen, TNC, and the studied defense metabolites than Asian and European pines (Figure 7B,D-G). Asian pines had a higher content of starch and TNC and a higher SLA value than American and European pines (Figure 7C,D,E,H). Moreover, pine trees of European and Asian origin were characterized by a lower content of the investigated defense metabolites compared to the American ones (Figure 7B,D-G). Three-needle pines were characterized by having the highest water content (Figure 8A), but two-needle pines had a lower nitrogen content (Figure 8B). In the case of starch and TNC, the highest values were recorded for two-, five-, and three-needle pines, respectively (Figure 8C,D). Fiveneedle pine species had the lowest content of TPh and tannins, but a higher SLA value than two- and three-needle pine species (Figure 8E,F,H). The number of needles in fascicles did not influence TT content. The influence of months of plant material collection during the insect feeding period was found when analyzing different species of pine origin, but in plants with varying numbers of needles in fascicles, the influence of these months of plant material collection was significant only in starch and TNC (Table 3). 


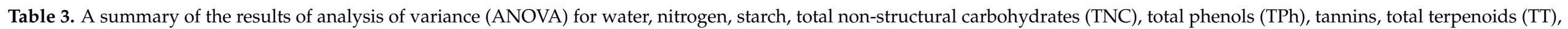

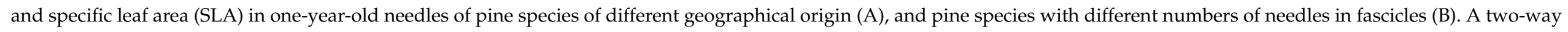

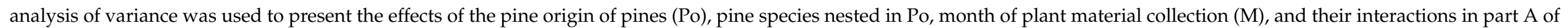

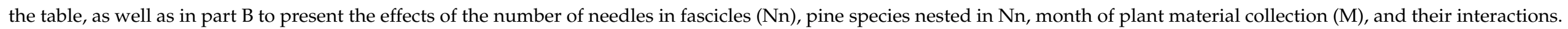
Statistically significant differences $p<0.05$ are marked in bold.

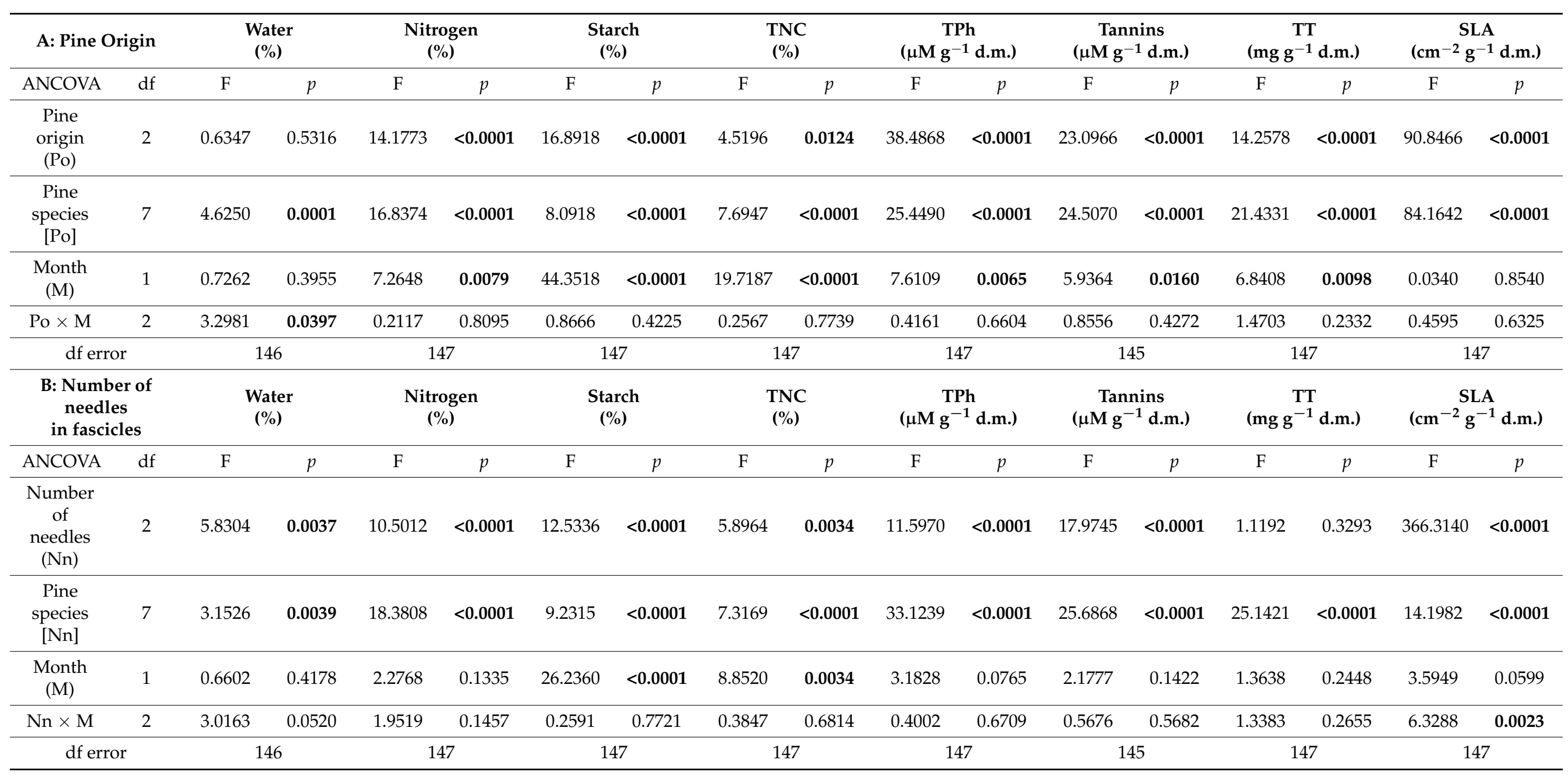



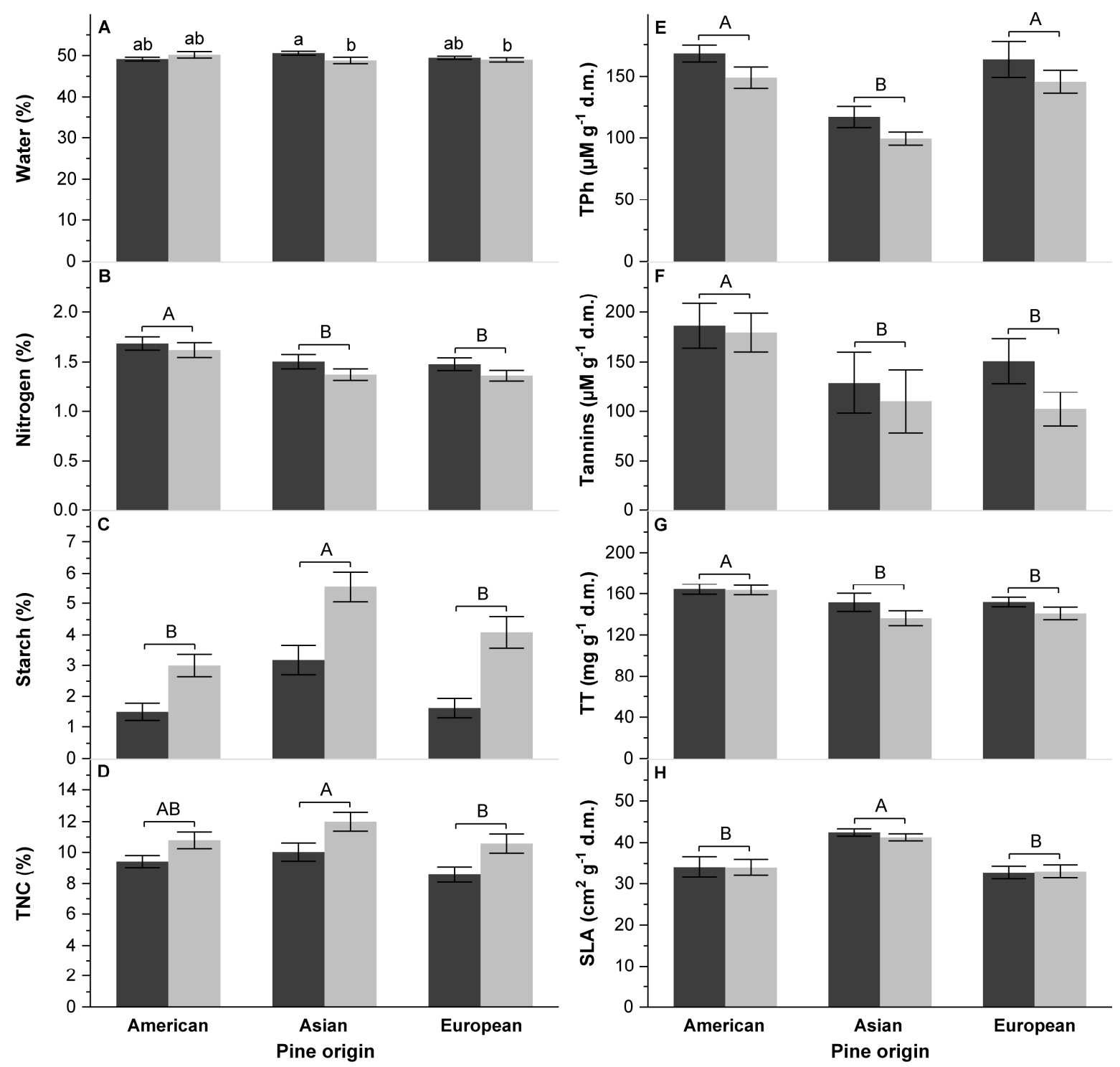

Figure 7. Mean values ( \pm SE) of water (A), nitrogen $(\mathbf{B})$, starch $(\mathbf{C})$, total non-structural carbohydrates (TNC; D), total phenols (TPh; E), tannins (F), and total terpenoids content (TT; G), as well as specific leaf area (SLA; H), of needles of pines of different geographical origin (American, Asian, and European) achieved over two consecutive months of collection of plant material-April (dark) and May (light). Lowercase letters above the bars indicate result of Tukey's post hoc test $(\alpha=0.05)$ for interaction pine origin $\times$ month, and uppercase letters indicate result for pine origin treatment (see also Table 3). Levels not connected by same letter are significantly different. 

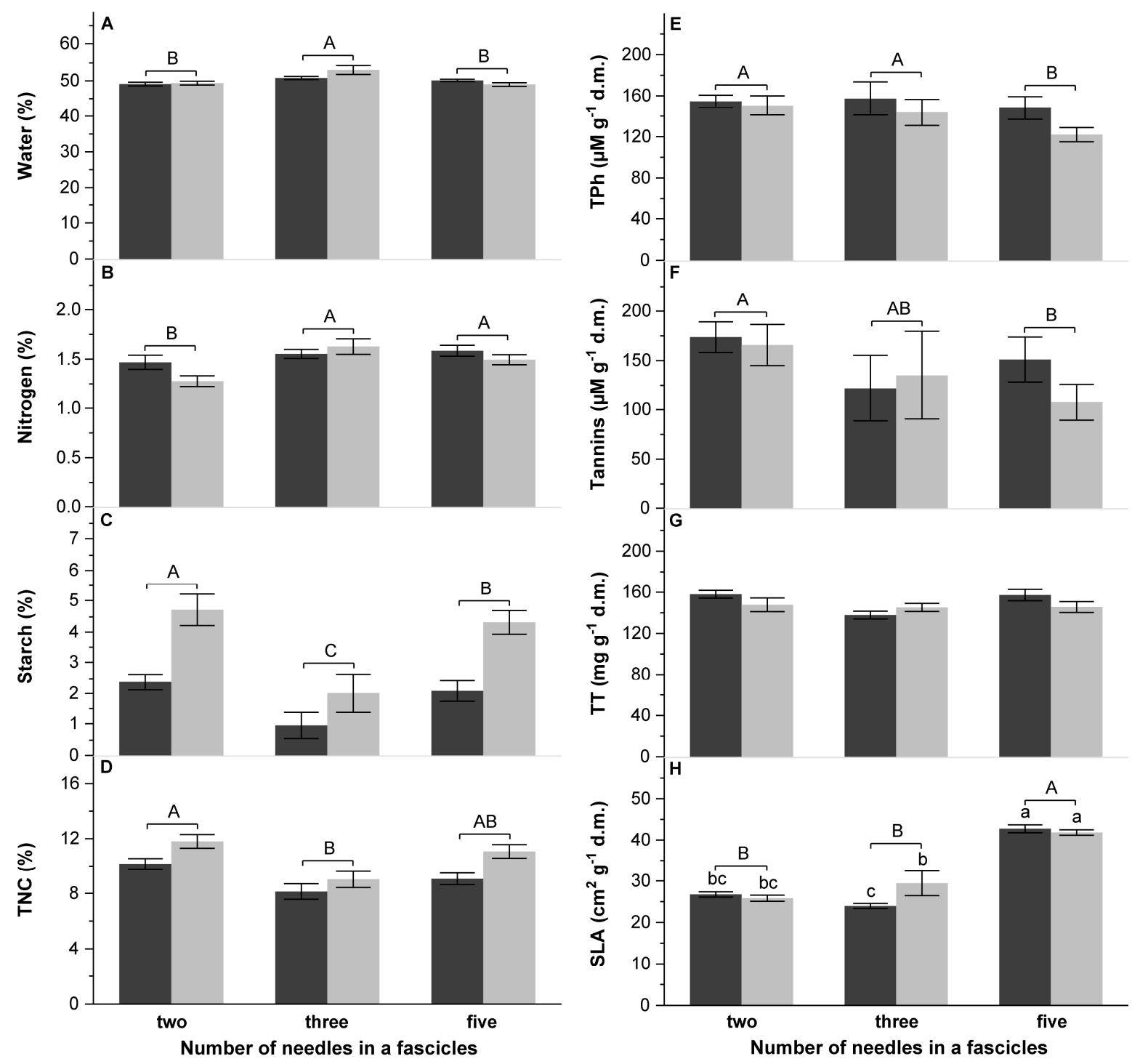

Figure 8. Mean values $( \pm$ SE) of water $(\mathbf{A})$, nitrogen $(\mathbf{B})$, starch $(\mathbf{C})$, TNC $(\mathbf{D})$, TPh $(\mathbf{E})$, tannins $(\mathbf{F})$, and TT $(\mathbf{G})$, as well as SLA $(\mathbf{H})$, of needles of pine species with different numbers of needles in fascicles (two, three, and five) achieved over two consecutive months of collection of plant material-April (dark) and May (light). Lowercase letters above the bars indicate result of Tukey's post hoc test $(\alpha=0.05)$ for interaction number of needles $\times$ month, and uppercase letters indicate result for number of needles treatment (see also Table 3). Levels not connected by same letter are significantly different.

\section{Discussion}

\subsection{Host Plant Preferences}

We provided new insights into the effects of the host plant on oligophagous DP. The study of the influence of pine species other than the primal host on the preferences and performance of this species is an additional step toward learning more about the ecology of this important pest [33]. There are already some reports that have been conducted for other species of the genus Dendrolimus sp. Germar, as they are all serious pests and, therefore, attract more attention from scientists [28,63-65]. Larvae's active food selection is the result of seeking the best-quality food that will provide the fastest growth and development. Indeed, larvae using the independently selected food source as a host showed direct benefits in adult reproductive performance [2,11,15,43,66-68]. Herbivorous insect species, particularly the specialists to which the group DP belongs, must have mechanisms for finding the best-quality food. In both experiments, where each larva had the opportunity to choose from this different host plant, it can be concluded that the larvae 
most willingly chose their primal host- $P$. sylvestris. However, there were also cases of selection of P. cembra, P. contorta, P. nigra, and P. ponderosa. Therefore, the results showed that this important Scots pine pest species accepts other pine species. It is highly likely that the choice of food by DP larvae was directed by volatile attractants of the needles, which allowed the optimization of the consumption of specific elements or substances. It is known that, for other insects, feeding preferences were attributed to foliage chemistry [69-71]. For DP, specific attractants were initially recognized, such as gallic acid and $\beta$-pinene [36]; however, their content in different hosts is not yet known. Our first question was answered as the results of our 10 and two options tests indicated larval preference for P. sylvestris, but also for other pine species; thus, we partly confirmed out hypothesis.

\subsection{Performance of DP on Various Pine Species}

Insufficient and non-preferred food would cause the resulting adults to be smaller than normal and/or would prolong the duration of development. However, it does not necessarily harm the growth and development of insects. Even an admixture of small amounts of non-preferred foods in a diet may enhance insect fitness [72]. Keena [32] found that several coniferous and deciduous species were suitable for L. monacha survival and development. She distinguished plant species that did not show differences in insect parameters between the basic food plant, that is, P. sylvestris (intermediate group), and groups of suitable and poor hosts, which caused, respectively, an increase or decrease in the values of indicators. Similarly, based on dual-choice and host plant suitability tests, Kirichenko et al. [64] divided potential hosts for Dendrolimus sibiricus Tschtv. into the same groups. Based on our results, we can clearly divide the studied host species into two groups: more suitable-comparably good quality similar to the primal host (P. cembra, $P$. contorta, P. nigra, and P. ponderosa) and less suitable-worse quality (P. armandii, P. koraiensis, P. peuce, P. strobus, and P. wallichiana).

There were non-significant differences in survival during the performance test between the larvae fed on needles of different pines species. These results confirmed that DP can extend its food base to new pine species, as evidenced by the very low level of mortality during the experiment (5-25\%). However, we presented data that showed a host-specific response of DP to the effects of host plant species other than primary host plant species. This response was manifested in a large variation in body masses as well as in a decrease or increase in life-history traits, such as fecundity (Tables A1 and A2). Among the many fitness parameters, the most frequently recognized and easily measured parameter is body mass [73-76]. In general, larger and heavier individuals live longer, have greater resistance to starvation, and have higher reproductive success than small individuals. Larger males are better competitors for access to females, and larger females produce more eggs. It is commonly considered axiomatic for most insects females that their increased mass and/or size results in increased fecundity [8,77]. Our results indicate that there is a strong fecundity advantage of large mass females of DP and a positive relationship between body mass and wing parameters. Much higher masses and sizes of female specimens than their male counterparts are common in the insect world [78]. In our experiments, all relationships with sex, noted for DP, were in line with the above results.

Although the change of host plant did not appear to affect DP survival, some studied parameters justify the division of the host into suitable groups adopted here. Results such as low body and cocoon masses; low values of RGR, AD, ECI, and ECD parameters; and a high value of the CI of a particular host indicate that its needles are not a sufficiently good food for DP larvae. In summary of this part, we can emphasize that we partly confirmed our second hypothesis, as survival is not dependent on the host treatments, but in some cases, feeding with pine species other than the basic food plant caused a reduction in key parameters. 


\subsection{Effect of Pine Species Origin and the Number of Needles in a Fascicle on DP Performance}

The selection of pine species for this research was made to take into account their importance worldwide, the diversity of their geographical occurrence, as well as the morphological structure of needles (i.e., different numbers of needles in fascicles). It is crucial to include many different species to learn about the potential possibility of invading and the emergence of a new population of insects in a distant place. Similarity in the results obtained for parameters of growth and development can be seen in European and American species, and significantly worse in Asian species (Figures 3 and 4). Therefore, we could speculate that if this insect species was introduced into new host plants/places in Europe (now free of this pest) or North America, it would likely be able to establish more easily in comparison to in Asia. Furthermore, all mass and various developmental consumption parameters indicate that feeding individuals on two- and three-needle pine species was comparable and better than in specimens from five-needle treatments. Noticeably, fiveneedle species cause a feeding problem for DP due to their morphological structure, especially compared to two-needle species. The anatomical and morphological features of needles, such as their length, width, or cross-sectional shape, vary greatly within the Pinus genus [79-83]. Connected needles from one fascicle have the shape of a cylinder, so the more needles emerge from one, the thinner (more flaccid) these needles are (the cylinder is divided into a larger number of parts) [83]. Older larvae of DP graze economically, grabbing a single needle with true legs and midabdominal prolegs in a specific way and eat it whole starting from its tip [38]. Thus, more than two needles in a fascicle, and thinner, longer, or shorter needles than needles of $P$. sylvestris, disturb larval consumption. In contrast, the SLA values of Asian and five-needle species were the highest, which indicates that needles were easier to consume (less tough), but more flaccid [84]. Apparently, the consumption behavior of the genus Dendrolimus sp. is strongly related to the morphological structure of the needles of the primal host plant. For example, Kirichenko et al. [64] found a reverse relationship in that $D$. sibiricus growth and development were worst in twoneedle pine species, as their primal hosts have many soft needles (five-needle P. sibirica $\mathrm{Du}$ Tour and Larix sibirica Ledebour). Concluding this part, we can highlight that we partly confirmed our third and fourth hypotheses. We expected that for DP both the geographic and morphological similarity to the primal host would be important here, but the results show that these relationships are not unequivocal. Larvae of DP also achieved higher values of growth, development, and morphological parameters when fed on American pine species and pine species with three needles in a fascicle.

\subsection{Influence of Chemical and Physical Characteristics of Pine Species on DP Performance}

Major indicators of needle resource quality are chemical composition (content of primary and secondary metabolites) and physical characteristics (e.g., toughness and trichomes) [85]. It is a well-recognized fact that these characteristics can significantly affect the survival rate, preference, feeding behavior, and reproductive success of herbivorous insects $[70,86,87]$. For the performance test, we determined that the pine species affected the needle quality, and thus influenced the larval growth and development. Our results indicate that higher levels of the studied secondary metabolites (TPh, tannins, and TT) in species of the less suitable group of hosts played an important role in achieving the worst performance of larvae fed with them. In the more suitable host species group, levels of the studied secondary metabolites did not differ significantly from the level of Scots pine or were even lower. On the other hand, our experiments did not show a significant role of water, nitrogen, and non-structural carbohydrates in the selection and performance of DP in pine needles of various origins and the number of needles in a fascicle. We can state that we confirmed our last hypothesis. The SLA as well as variation in the secondary metabolite composition of different pine species corresponded well with results found for the insects, but the content of sugars and nitrogen remains to be elucidated. 


\subsection{Application Aspects and Future Plans}

DP, with varying degrees of success, accepted, chewed, and survived on the pine species from different regions of the world with different morphologies and chemical compositions of needles. Therefore, this allows us to speculate that the entire Pinus genus could be included in future models of the potential distribution of this insect. In order for an insect to successfully invade new places, there are many additional requirements that must be met. Highly significant elements of the further dispersion of a species within a new environment are the periodicity of the anthropogenic vector, ability to survive transportation, and suitable climatic conditions [29,31,32]. We already showed [44] that DP larvae are characterized by the ability to survive simulated temporal starvation for two weeks (for up to a maximum of one month), thus confirming that this species could survive long passive dispersal periods. Here, we showed the high survival of individuals and their food plasticity on different hosts of the genus Pinus, which is an important argument in defining DP as a potentially invasive species that should be strictly monitored [88], as with other species from the genus Dendrolimus [64,89]. It should be noted, however, that the beginning of the spread of this pest may be hampered by worse wing size parameters as well as lower fecundity compared to those living in optimal conditions. Researchers usually utilize niche modeling to model locations of high compliance with insects' environmental requirements and preferred food [90]. We believe that it is important to model this range for DP. From a practical point of view, we are planning in the next step of our research to model the potential distribution of this dangerous pest.

\subsection{Study Limitations}

The design of our study had some limitations. First, our study was a typical laboratory experiment, where other factors that may prove to be important with respect to survival and development were omitted due to the ceteris paribus principle (humidity, light quality and quantity, temperature, etc.). It would be very difficult to carry out such extensive field research or to take into account other factors. Second, larval stress was minimalized during this experiment (absence of baculoviruses and predators, starvation, etc.). Therefore, we cannot simply convert the results obtained from this experiment for research that would be carried out under field conditions. Third, during the experiment, we used small containers and ad libitum feeding, which limited the possibility and needs of larvae starting intensive food searches, on the one hand [91], but on the other hand, minimized larval energy loss [92,93]; thus, the performance of insects may be higher than that observed in natural conditions. Moreover, it should be taken into account that the characteristics of the needles of alien species of pine determined in this study (ex situ), and thus their nutritional quality for the larvae, may differ more or less from that in situ. Finally, at this stage of research, we covered only a limited number of important trees as potential hosts for DP (only pines). In the near future, we are planning research that may cover more genera of important coniferous trees (Abies sp. Mill., Larix sp. Mill., Picea sp. A. Dietr., Pseudotsuga sp. Carrière, Tsuga sp. Carrière, etc.), similar to the work of other authors [28,64].

\section{Conclusions}

Results confirmed that DP can extend its food base to other pine species, as evidenced by the very low and non-significant level of mortality during the experiments. We found that this insect preferred mainly its primal host plant, $P$. sylvestris, but there were other species (P. cembra, P. contorta, P. nigra, and P. ponderosa) that were also more likely to be chosen in relation to the remaining ones. The larvae's choice of a particular host corresponds to the results of the performance test-more willingly selected food, enabling better results in the performance in these larvae. Variation in the SLA as well as secondary metabolite composition of different pine species effectively explained the results found for the insects. On the basis of the many investigated parameters, we could conclude that larvae fed on pine species from Europe and America or on species with two and three needles in fascicles as compared to Asian and five-needle species, respectively, achieved better values for final 
body mass, growth, and development. Taking all considerations into account from this and our previous research, we generally conclude that DP larvae are characterized by their high ability to survive without food [44] and successful recovery on a different host. Therefore, we confirm that this species can survive migration periods to almost anywhere in the world using anthropogenic vectors, and later, when its development was completed, representatives of this species can start a new population on a new host.

Author Contributions: Conceptualization, A.Ł.; methodology, A.Ł., M.J.G., and P.K.; formal analysis, A.Ł.; investigation, A.Ł., D.A., and E.M.; resources, A.Ł., D.A., and E.M.; writing-original draft preparation, A.E.; writing—review and editing, P.K. and M.J.G.; visualization, A.E.; supervision, P.K.; project administration, A.E. and P.K.; funding acquisition, A.E. All authors have read and agreed to the published version of the manuscript.

Funding: This research was financially supported by the National Science Centre, Poland (grant No. 2016/23/N/NZ9/02755).

Institutional Review Board Statement: Not applicable.

Informed Consent Statement: Not applicable.

Data Availability Statement: The data presented in this study are available upon request from the corresponding author.

Acknowledgments: We are grateful to Roma Żytkowiak from the Institute of Dendrology for help with laboratory works. We would like to thank the two anonymous reviewers for their comments, which were helpful in improving the final version of the article.

Conflicts of Interest: The authors declare no conflict of interest. The funders had no role in the design of the study; in the collection, analyses, or interpretation of data; in the writing of the manuscript; or in the decision to publish the results. 


\section{Appendix A}

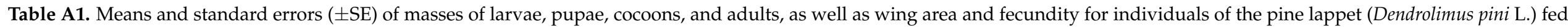

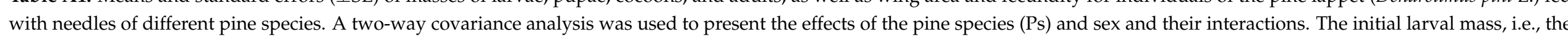

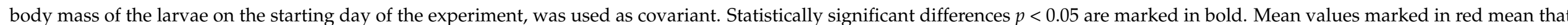

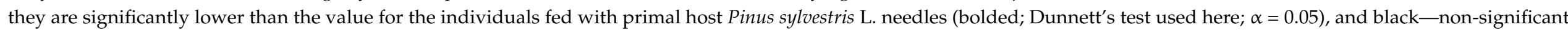
differences. The Dunnett's test was performed for the Ps factor, so there was no sex differentiation, thus two cells (for female and male) are marked in color.

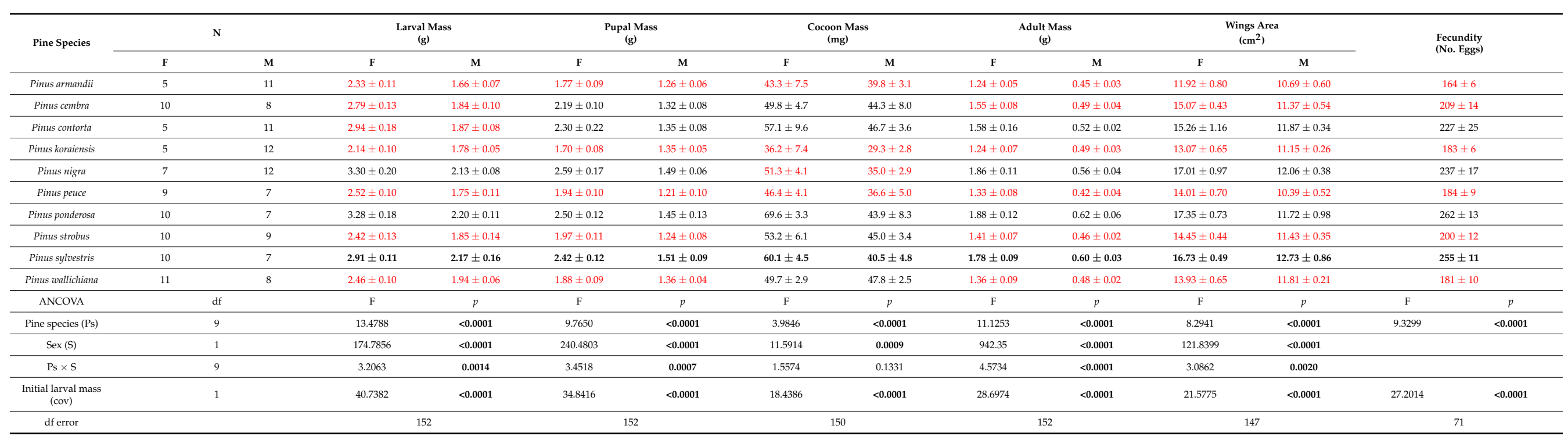




\section{Appendix B}

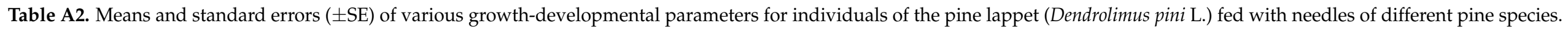

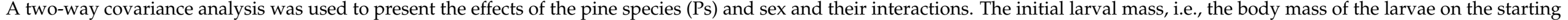

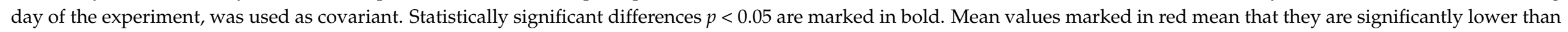

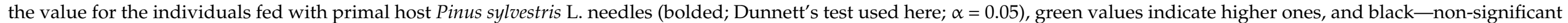
differences. The Dunnett's test was performed for the Ps factor, so there was no sex differentiation, thus two cells (for female and male) are marked in color.

\begin{tabular}{|c|c|c|c|c|c|c|c|c|c|c|c|c|c|c|c|c|c|c|}
\hline \multirow{2}{*}{ Pine Species } & \multicolumn{2}{|c|}{$\mathrm{N}$} & \multicolumn{2}{|c|}{$\begin{array}{c}\mathrm{DD} \\
\text { (day) }\end{array}$} & \multicolumn{2}{|c|}{$\begin{array}{c}\mathrm{PP} \\
\text { (day) }\end{array}$} & \multicolumn{2}{|c|}{$\begin{array}{c}\mathrm{TFE} \\
\text { (g d.m.). }\end{array}$} & \multicolumn{2}{|c|}{$\left(\mathrm{g} \mathrm{g}^{-1}\right.$ day $\left.^{-1}\right)$} & \multicolumn{2}{|c|}{$\left(\mathrm{g} \mathrm{g}^{-1} \mathrm{day}_{\text {day }}^{-1}\right)$} & \multicolumn{2}{|c|}{$\begin{array}{l}\mathrm{AD} \\
(\%)\end{array}$} & \multicolumn{2}{|c|}{$\begin{array}{l}\mathrm{ECI} \\
(\%)\end{array}$} & \multicolumn{2}{|c|}{$\begin{array}{l}\text { ECD } \\
(\%)\end{array}$} \\
\hline & $\mathrm{F}$ & M & $\mathrm{F}$ & M & $\mathrm{F}$ & $\mathrm{M}$ & $\mathrm{F}$ & M & $\mathrm{F}$ & M & $\mathrm{F}$ & M & $\mathrm{F}$ & M & $\mathrm{F}$ & $\mathrm{M}$ & $\mathrm{F}$ & M \\
\hline $\begin{array}{c}\text { Pinus } \\
\text { armandii }\end{array}$ & 5 & 11 & $40.2 \pm 4.7$ & $32.9 \pm 2.0$ & $24.2 \pm 1.7$ & $28.6 \pm 1.2$ & $7.78 \pm 0.72$ & $5.49 \pm 0.18$ & $\begin{array}{c}0.086 \pm \\
0.010 \\
\end{array}$ & $\begin{array}{c}0.103 \pm \\
0.005 \\
\end{array}$ & $\begin{array}{c}0.0140 \pm \\
0.0015 \\
\end{array}$ & $\begin{array}{c}0.0166 \pm \\
0.0013 \\
\end{array}$ & $33.60 \pm 1.93$ & $39.35 \pm 1.38$ & $16.61 \pm 1.59$ & $15.93 \pm 1.14$ & $50.33 \pm 5.86$ & $41.27 \pm 3.65$ \\
\hline Pinus cembra & 10 & 8 & $36.3 \pm 2.1$ & $29.8 \pm 0.6$ & $25.6 \pm 0.8$ & $27.5 \pm 0.7$ & $8.31 \pm 0.41$ & $5.93 \pm 0.25$ & $\begin{array}{c}0.083 \pm \\
0.002 \\
\end{array}$ & $\begin{array}{c}0.110 \pm \\
0.003 \\
\end{array}$ & $\begin{array}{c}0.0177 \pm \\
0.0010 \\
\end{array}$ & $\begin{array}{c}0.0185 \pm \\
0.0022 \\
\end{array}$ & $42.44 \pm 1.10$ & $49.89 \pm 2.58$ & $21.23 \pm 0.82$ & $17.22 \pm 2.32$ & $50.75 \pm 3.18$ & $36.38 \pm 5.78$ \\
\hline $\begin{array}{c}\text { Pinus } \\
\text { contorta }\end{array}$ & 5 & 11 & $35.2 \pm 4.6$ & $27.4 \pm 1.6$ & $26.2 \pm 2.0$ & $28.0 \pm 0.9$ & $8.26 \pm 0.40$ & $5.20 \pm 0.37$ & $\begin{array}{c}0.084 \pm \\
0.008 \\
\end{array}$ & $\begin{array}{c}0.103 \pm \\
0.006 \\
\end{array}$ & $\begin{array}{c}0.0191 \pm \\
0.0020 \\
\end{array}$ & $\begin{array}{c}0.0228 \pm \\
0.0027 \\
\end{array}$ & $39.51 \pm 1.08$ & $52.13 \pm 5.12$ & $22.70 \pm 1.24$ & $24.20 \pm 5.04$ & $57.78 \pm 4.20$ & $45.12 \pm 5.01$ \\
\hline $\begin{array}{c}\begin{array}{c}\text { Pinus } \\
\text { koraiensis }\end{array} \\
\end{array}$ & 5 & 12 & $46.8 \pm 3.4$ & $30.9 \pm 1.9$ & $22.8 \pm 1.7$ & $27.9 \pm 0.8$ & $8.20 \pm 0.84$ & $5.26 \pm 0.43$ & $\begin{array}{c}0.083 \pm \\
0.007\end{array}$ & $\begin{array}{c}0.096 \pm \\
0.003 \\
\end{array}$ & $\begin{array}{c}0.0135 \pm \\
0.0014 \\
\end{array}$ & $\begin{array}{r}0.0159 \pm \\
0.0010 \\
\end{array}$ & $46.78 \pm 2.89$ & $44.54 \pm 2.21$ & $16.35 \pm 0.91$ & $16.85 \pm 1.14$ & $35.39 \pm 2.58$ & $38.95 \pm 3.42$ \\
\hline Pinus nigra & 7 & 12 & $36.9 \pm 5.1$ & $25.3 \pm 2.9$ & $28.4 \pm 1.2$ & $28.3 \pm 0.9$ & $9.95 \pm 0.65$ & $5.77 \pm 0.44$ & $\begin{array}{c}0.088 \pm \\
0.008 \\
\end{array}$ & $\begin{array}{c}0.115 \pm \\
0.008 \\
\end{array}$ & $\begin{array}{c}0.0218 \pm \\
0.0024 \\
\end{array}$ & $\begin{array}{c}0.0249 \pm \\
0.0018 \\
\end{array}$ & $49.04 \pm 5.20$ & $40.53 \pm 4.17$ & $24.75 \pm 1.61$ & $22.10 \pm 1.42$ & $51.88 \pm 3.51$ & $59.63 \pm 5.38$ \\
\hline Pinus pence & 9 & 7 & $34.9 \pm 1.6$ & $30.6 \pm 2.5$ & $25.2 \pm 0.9$ & $28.3 \pm 0.8$ & $6.73 \pm 0.37$ & $4.17 \pm 0.50$ & $\begin{array}{c}0.078 \pm \\
0.004\end{array}$ & $\begin{array}{c}0.081 \pm \\
0.011\end{array}$ & $\begin{array}{c}0.0170 \pm \\
0.0008 \\
\end{array}$ & $\begin{array}{c}0.0206 \pm \\
0.0015 \\
\end{array}$ & $41.73 \pm 2.74$ & $53.73 \pm 6.57$ & $22.25 \pm 1.31$ & $31.11 \pm 7.67$ & $55.00 \pm 4.38$ & $54.98 \pm 6.89$ \\
\hline $\begin{array}{c}\text { Pinus } \\
\text { ponderosa }\end{array}$ & 10 & 7 & $28.9 \pm 2.1$ & $33.4 \pm 5.5$ & $27.3 \pm 0.8$ & $25.3 \pm 1.5$ & $8.82 \pm 0.25$ & $7.80 \pm 0.50$ & $\begin{array}{c}0.097 \pm \\
0.004 \\
\end{array}$ & $\begin{array}{c}0.120 \pm \\
0.014 \\
\end{array}$ & $\begin{array}{c}0.0256 \pm \\
0.0013 \\
\end{array}$ & $\begin{array}{c}0.0203 \pm \\
0.0031 \\
\end{array}$ & $53.89 \pm 5.15$ & $55.75 \pm 3.41$ & $26.77 \pm 1.62$ & $16.65 \pm 1.08$ & $51.79 \pm 3.82$ & $30.76 \pm 2.90$ \\
\hline Pinus strobus & 10 & 9 & $35.0 \pm 2.5$ & $28.3 \pm 2.5$ & $27.2 \pm 1.1$ & $27.8 \pm 0.7$ & $5.63 \pm 0.32$ & $4.31 \pm 0.35$ & $\begin{array}{c}0.069 \pm \\
0.004\end{array}$ & $\begin{array}{c}0.087 \pm \\
0.008\end{array}$ & $\begin{array}{c}0.0175 \pm \\
0.0009\end{array}$ & $\begin{array}{c}0.0220 \pm \\
0.0022\end{array}$ & $44.44 \pm 3.29$ & $54.07 \pm 4.43$ & $26.21 \pm 2.33$ & $27.79 \pm 4.99$ & $60.10 \pm 4.42$ & $50.54 \pm 5.88$ \\
\hline $\begin{array}{c}\text { Pinus } \\
\text { sylvestris }\end{array}$ & 10 & 7 & $28.6 \pm 1.2$ & $28.3 \pm 3.6$ & $29.8 \pm 0.8$ & $28.4 \pm 1.1$ & $7.10 \pm 0.38$ & $5.38 \pm 0.79$ & $\begin{array}{c}0.086 \pm \\
0.004 \\
\end{array}$ & $\begin{array}{c}0.091 \pm \\
0.008 \\
\end{array}$ & $\begin{array}{c}0.0241 \pm \\
0.0013 \\
\end{array}$ & $\begin{array}{c}0.0288 \pm \\
0.0050 \\
\end{array}$ & $49.09 \pm 2.76$ & $69.54 \pm 5.36$ & $28.56 \pm 2.06$ & $35.42 \pm 8.25$ & $58.78 \pm 3.69$ & $\begin{array}{r}50.51 \pm \\
10.43 \\
\end{array}$ \\
\hline $\begin{array}{c}\text { Pinus } \\
\text { wallichiana }\end{array}$ & 11 & 8 & $35.9 \pm 2.4$ & $24.0 \pm 1.1$ & $25.5 \pm 0.6$ & $26.1 \pm 0.6$ & $7.52 \pm 0.32$ & $5.56 \pm 0.23$ & $\begin{array}{c}0.088 \pm \\
0.005 \\
\end{array}$ & $\begin{array}{c}0.122 \pm \\
0.008 \\
\end{array}$ & $\begin{array}{c}0.0193 \pm \\
0.0010 \\
\end{array}$ & $\begin{array}{c}0.0235 \pm \\
0.0012 \\
\end{array}$ & $54.68 \pm 2.72$ & $47.63 \pm 2.44$ & $22.25 \pm 1.03$ & $19.69 \pm 1.07$ & $41.78 \pm 3.03$ & $42.58 \pm 3.74$ \\
\hline ANCOVA & & & $\mathrm{F}$ & $p$ & $\mathrm{~F}$ & $p$ & $\mathrm{~F}$ & $p$ & $\mathrm{~F}$ & $p$ & $\mathrm{~F}$ & $p$ & $\mathrm{~F}$ & $p$ & $\mathrm{~F}$ & $p$ & $\mathrm{~F}$ & $p$ \\
\hline $\begin{array}{c}\text { Pine species } \\
(\mathrm{Ps})\end{array}$ & & & 3.8039 & 0.0002 & 2.5756 & 0.0087 & 10.9865 & $<0.0001$ & 4.5752 & $<0.0001$ & 6.0806 & $<0.0001$ & 5.1063 & $<0.0001$ & 5.6397 & $<0.0001$ & 3.4757 & 0.0006 \\
\hline $\mathrm{Ps}_{\mathrm{s}} \times \mathrm{S}$ & & & 1.8530 & 0.0632 & 2.5016 & 0.0107 & 2.2821 & 0.0199 & 0.8829 & 0.5421 & 1.3465 & 0.2176 & 2.3083 & 0.0185 & 1.3918 & 0.1964 & 1.9517 & 0.0487 \\
\hline $\begin{array}{c}\text { Initial larval } \\
\text { mass (cov) }\end{array}$ & & & 26.9481 & $<0.0001$ & 1.6807 & 0.1968 & 0.2121 & 0.6458 & 1.0073 & 0.3172 & 8.7103 & 0.0037 & 4.4652 & 0.0362 & 10.5231 & 0.0014 & 2.8394 & 0.0940 \\
\hline df error & & & & & & & & & & & & & & & & & & \\
\hline
\end{tabular}

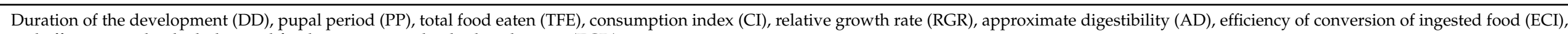
and efficiency with which digested food was converted to body substance (ECD). 


\section{Appendix C}

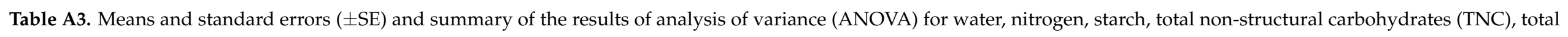

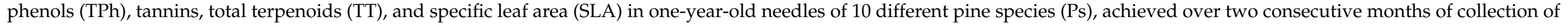

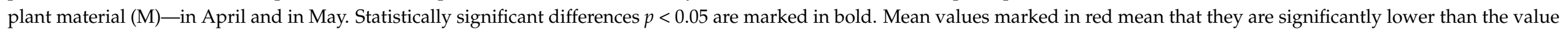

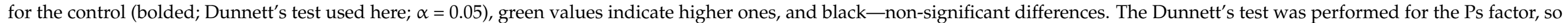
there was no month differentiation, thus two cells (for April and May) are marked in color.

\begin{tabular}{|c|c|c|c|c|c|c|c|c|c|c|c|c|c|c|c|c|c|c|}
\hline \multirow{2}{*}{ Pine Species } & \multicolumn{2}{|c|}{$\mathrm{N}$} & \multicolumn{2}{|c|}{$\begin{array}{c}\text { Water } \\
(\%)\end{array}$} & \multicolumn{2}{|c|}{$\begin{array}{c}\text { Nitrogen } \\
(\%)\end{array}$} & \multicolumn{2}{|c|}{$\begin{array}{c}\text { Starch } \\
(\%)\end{array}$} & \multicolumn{2}{|c|}{$\begin{array}{l}\mathrm{TNC} \\
(\%)\end{array}$} & \multicolumn{2}{|c|}{$\begin{array}{c}\mathrm{TPh} \\
\left(\mu \mathrm{Mg}^{-1} \text { d.m. }\right)\end{array}$} & \multicolumn{2}{|c|}{$\begin{array}{c}\text { Tannins } \\
\left(\mu \mathrm{M} \mathrm{g}^{-1} \text { d.m. }\right)\end{array}$} & \multicolumn{2}{|c|}{$\left(\mathrm{mg}^{-1 \mathrm{~T}}\right.$ g d.m. $)$} & \multicolumn{2}{|c|}{$\begin{array}{c}\text { SLA } \\
\text { (cm-1 g g.m.) }\end{array}$} \\
\hline & April & May & April & May & April & May & April & May & April & May & April & May & April & May & April & May & April & May \\
\hline $\begin{array}{c}\text { Pinus } \\
\text { armandii }\end{array}$ & 8 & 8 & $52.1 \pm 0.6$ & $51.2 \pm 0.8$ & $1.29 \pm 0.07$ & $1.33 \pm 0.14$ & $3.43 \pm 0.43$ & $6.77 \pm 0.68$ & $11.10 \pm 0.50$ & $13.92 \pm 0.91$ & $150.6 \pm 12.3$ & $103.7 \pm 6.1$ & $299.6 \pm 54.0$ & $235.9 \pm 76.5$ & $208.1 \pm 1.9$ & $158.1 \pm 15.2$ & $42.6 \pm 1.2$ & $43.3 \pm 1.2$ \\
\hline Pinus cembra & 8 & 8 & $48.6 \pm 0.7$ & $51.2 \pm 1.4$ & $1.70 \pm 0.15$ & $1.49 \pm 0.07$ & $1.77 \pm 1.01$ & $2.15 \pm 0.81$ & $7.92 \pm 1.62$ & $7.33 \pm 1.12$ & $78.9 \pm 2.4$ & $101.2 \pm 7.4$ & $23.8 \pm 5.7$ & $18.5 \pm 2.3$ & $121.4 \pm 4.5$ & $112.7 \pm 3.6$ & $34.3 \pm 0.8$ & $38.5 \pm 1.1$ \\
\hline $\begin{array}{c}\text { Pinus } \\
\text { contorta }\end{array}$ & 8 & 8 & $48.2 \pm 1.1$ & $51.2 \pm 0.9$ & $1.49 \pm 0.13$ & $1.26 \pm 0.05$ & $2.88 \pm 0.38$ & $2.98 \pm 0.48$ & $11.31 \pm 0.51$ & $9.84 \pm 0.52$ & $178.8 \pm 11.2$ & $173.1 \pm 17.1$ & $184.1 \pm 22.9$ & $224.6 \pm 25.3$ & $174.0 \pm 7.7$ & $170.6 \pm 8.1$ & $28.8 \pm 0.6$ & $27.6 \pm 1.3$ \\
\hline $\begin{array}{c}\begin{array}{c}\text { Pinus } \\
\text { koraiensis }\end{array} \\
\text { (n) }\end{array}$ & 8 & 8 & $48.9 \pm 0.6$ & $47.7 \pm 1.6$ & $1.43 \pm 0.07$ & $1.30 \pm 0.06$ & $4.38 \pm 1.18$ & $5.18 \pm 0.90$ & $11.27 \pm 1.24$ & $11.48 \pm 0.68$ & $120.0 \pm 8.9$ & $114.6 \pm 9.5$ & $47.5 \pm 10.4$ & $50.2 \pm 20.7$ & $127.8 \pm 6.0$ & $128.5 \pm 10.1$ & $38.7 \pm 1.0$ & $37.6 \pm 1.2$ \\
\hline Pinus nigra & 8 & 8 & $50.7 \pm 0.8$ & $47.9 \pm 0.7$ & $1.16 \pm 0.05$ & $1.07 \pm 0.05$ & $1.88 \pm 0.43$ & $5.67 \pm 1.04$ & $8.66 \pm 0.53$ & $12.21 \pm 0.83$ & $140.7 \pm 8.1$ & $123.4 \pm 12.6$ & $216.6 \pm 24.6$ & $147.1 \pm 49.2$ & $153.1 \pm 1.8$ & $128.4 \pm 11.2$ & $24.1 \pm 1.0$ & $22.1 \pm 0.5$ \\
\hline Pinus pence & 8 & 8 & $50.7 \pm 0.6$ & $48.3 \pm 0.7$ & $1.30 \pm 0.05$ & $1.39 \pm 0.13$ & $0.47 \pm 0.04$ & $3.02 \pm 0.96$ & $7.33 \pm 0.48$ & $9.51 \pm 0.97$ & $290.6 \pm 12.4$ & $202.8 \pm 14.2$ & $273.3 \pm 61.8$ & $118.2 \pm 30.9$ & $179.7 \pm 4.2$ & $177.8 \pm 8.6$ & $45.4 \pm 1.6$ & $43.7 \pm 1.7$ \\
\hline $\begin{array}{c}\text { Pinus } \\
\text { ponderosa }\end{array}$ & 8 & 8 & $50.6 \pm 0.4$ & $55.9 \pm 3.2$ & $1.55 \pm 0.05$ & $1.63 \pm 0.08$ & $0.97 \pm 0.43$ & $2.01 \pm 0.62$ & $8.13 \pm 0.56$ & $9.01 \pm 0.59$ & $157.4 \pm 16.2$ & $143.8 \pm 12.8$ & $121.9 \pm 33.3$ & $135.1 \pm 44.5$ & $137.8 \pm 3.7$ & $145.2 \pm 3.9$ & $24.0 \pm 0.6$ & $29.4 \pm 3.0$ \\
\hline Pinus strobus & 8 & 8 & $48.7 \pm 0.4$ & $46.9 \pm 1.0$ & $2.01 \pm 0.06$ & $1.97 \pm 0.10$ & $0.67 \pm 0.10$ & $4.05 \pm 0.60$ & $8.91 \pm 0.36$ & $13.58 \pm 0.70$ & $168.9 \pm 6.0$ & $130.0 \pm 11.7$ & $252.7 \pm 45.8$ & $178.5 \pm 22.4$ & $181.3 \pm 4.5$ & $174.8 \pm 8.0$ & $49.5 \pm 3.1$ & $45.0 \pm 1.4$ \\
\hline $\begin{array}{c}\text { Pinus } \\
\text { sylvestris }\end{array}$ & 8 & 8 & $47.9 \pm 0.6$ & $48.6 \pm 0.8$ & $1.75 \pm 0.09$ & $1.51 \pm 0.10$ & $2.37 \pm 0.49$ & $5.51 \pm 0.77$ & $10.50 \pm 0.65$ & $13.35 \pm 0.78$ & $144.3 \pm 6.6$ & $155.4 \pm 15.4$ & $120.2 \pm 23.4$ & $125.5 \pm 20.6$ & $146.9 \pm 4.5$ & $144.3 \pm 10.5$ & $27.3 \pm 1.0$ & $27.9 \pm 0$. \\
\hline 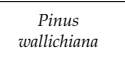 & 8 & 8 & $50.7 \pm 0.9$ & $47.6 \pm 1.3$ & $1.79 \pm 0.15$ & $1.50 \pm 0.08$ & $1.76 \pm 0.35$ & $4.70 \pm 0.87$ & $7.81 \pm 0.67$ & $10.59 \pm 1.22$ & $79.7 \pm 11.3$ & $79.7 \pm 7.4$ & $39.8 \pm 10.0$ & $44.2 \pm 20.6$ & $118.7 \pm 6.3$ & $121.9 \pm 8.3$ & $45.9 \pm 1.2$ & $42.8 \pm 1.1$ \\
\hline ANCOVA & & & $\mathrm{F}$ & $p$ & $\mathrm{~F}$ & $p$ & $\mathrm{~F}$ & $p$ & $\mathrm{~F}$ & $p$ & $\mathrm{~F}$ & $p$ & $\mathrm{~F}$ & $p$ & $\mathrm{~F}$ & $p$ & $\mathrm{~F}$ & $p$ \\
\hline $\begin{array}{c}\text { Pine species } \\
(\mathrm{Ps})\end{array}$ & & & 4.2619 & $<0.0001$ & 13.9862 & $<0.0001$ & 6.5146 & $<0.0001$ & 7.8032 & $<0.0001$ & 35.4660 & $<0.0001$ & 11.6377 & $<0.0001$ & 23.8333 & $<0.0001$ & 76.4862 & $<0.0001$ \\
\hline Month (M) & & & 0.0198 & 0.8883 & 6.4118 & 0.0124 & 47.2320 & $<0.0001$ & 23.0207 & $<0.0001$ & 13.4157 & 0.0004 & 3.7172 & 0.0559 & 7.6507 & 0.0064 & 0.1800 & 0.6720 \\
\hline Ps $\times$ M & & & 3.1534 & 0.0017 & 1.1726 & 0.3171 & 2.0219 & 0.0411 & 2.7440 & 0.0056 & 4.1476 & $<0.0001$ & 1.3375 & 0.2231 & 2.4973 & 0.0112 & 2.3633 & 0.0162 \\
\hline
\end{tabular}


Appendix D

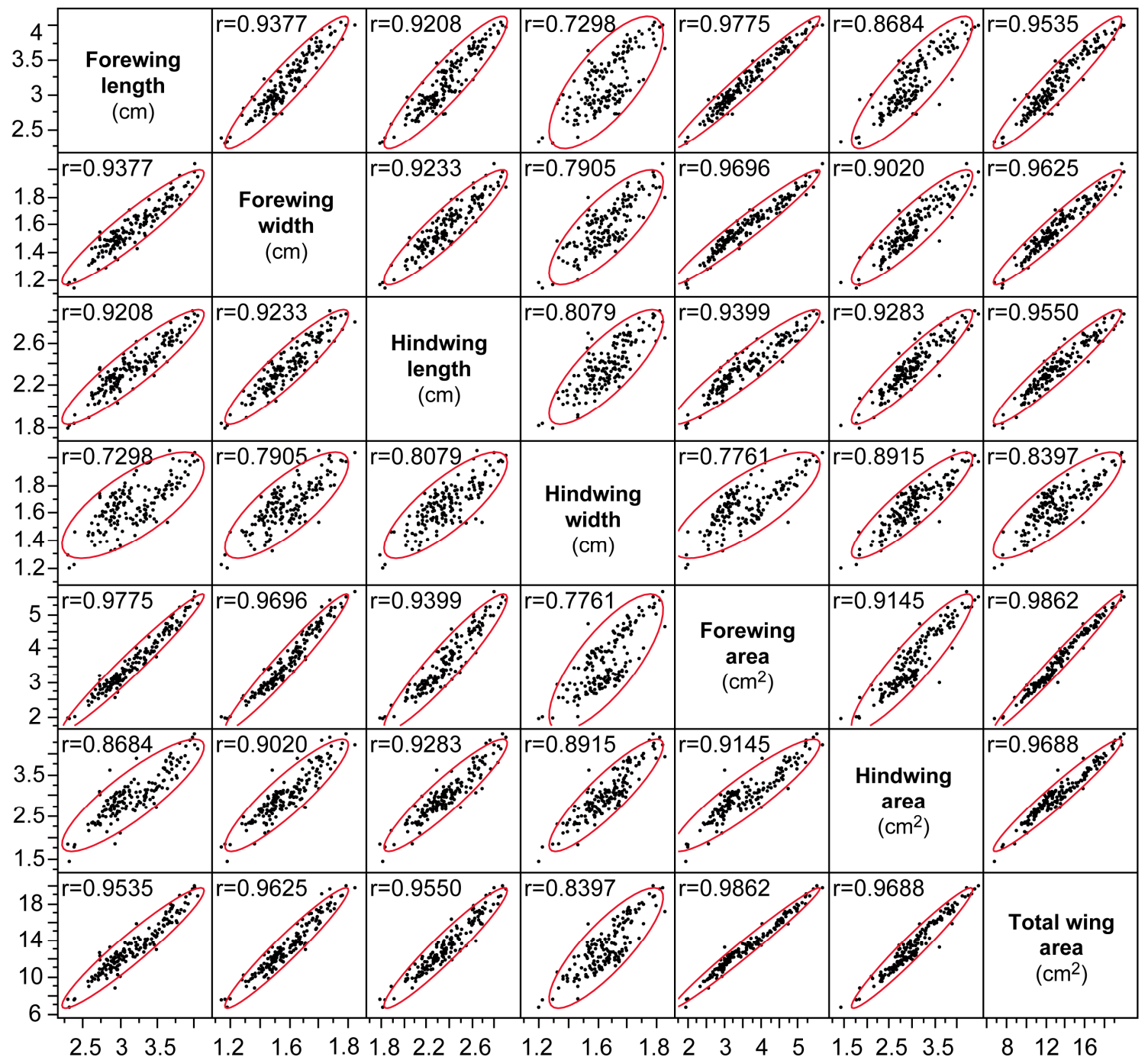

Figure A1. Matrix showing the linear relationships between the morphological parameters of the wings of pine-tree lappet Dendrolimus pini L. for the data collected in the performance test with feeding them with different species of pines. The ellipses for $\alpha=0.95$ are marked in red.

\section{References}

1. Howe, G.A.; Jander, G. Plant Immunity to Insect Herbivores. Annu. Rev. Plant Biol. 2008, 59, 41-66. [CrossRef] [PubMed]

2. Giertych, M.; Karolewski, P.; Grzebyta, J.; Oleksyn, J. Feeding behavior and performance of Neodiprion sertifer larvae reared on Pinus sylvestris needles. For. Ecol. Manag. 2007, 242, 700-707. [CrossRef]

3. Coll, M.; Yuval, B. Larval Food Plants Affect Flight and Reproduction in an Oligophagous Insect Herbivore. Environ. Entomol. 2004, 33, 1471-1476. [CrossRef]

4. Poelman, E.H. From induced resistance to defence in plant-insect interactions. Entomol. Exp. Appl. 2015, 157, 11-17. [CrossRef]

5. Pagare, S.; Bhatia, M.; Tripathi, N.; Pagare, S.; Bansal, Y.K. Secondary metabolites of plants and their role: Overview. Curr. Trends Biotechnol. Pharm. 2015, 9, 293-304.

6. Lucas, P.W.; Turner, I.M.; Dominy, N.; Yamashita, N. Mechanical Defences to Herbivory. Ann. Bot. 2000, 86, 913-920. [CrossRef]

7. Kolosova, N.; Bohlmann, J. Conifer defense against insects and fungal pathogens. In Growth and Defence in Plants; Springer: Berlin/Heidelberg, Gaermany, 2012; pp. 85-109. ISBN 978-3-64230-645-7.

8. Awmack, C.S.; Leather, S. Host Plant Quality and Fecundity in Herbivorous Insects. Annu. Rev. Entomol. 2002, 47, 817-844. [CrossRef]

9. Koricheva, J.; Larsson, S.; Haukioja, E. Insect Performance on Experimentally Stressed Woody Plants: A Meta-Analysis. Annu. Rev. Entomol. 1998, 43, 195-216. [CrossRef] 
10. Tammaru, T.; Haukioja, E. Capital Breeders and Income Breeders among Lepidoptera: Consequences to Population Dynamics. Oikos 1996, 77, 561. [CrossRef]

11. Gripenberg, S.; Mayhew, P.J.; Parnell, M.; Roslin, T. A meta-analysis of preference-performance relationships in phytophagous insects. Ecol. Lett. 2010, 13, 383-393. [CrossRef]

12. Carvalho, M.R.M.; Vasconcellos-Neto, J. Host plant selection and larval performance in the Neotropical butterfly Mechanitis polymnia casabranca. Entomol. Exp. Appl. 2021, 169, 255-263. [CrossRef]

13. Walczak, U.; Baraniak, E.; Zduniak, P. Survival, body mass and potential fecundity of the invasive moth Cameraria ohridella (Lepidoptera: Gracillariidae) on its original host plant Aesculus hippocastanum and Aesculus glabra. Eur. J. Entomol. 2017, 114, 295-300. [CrossRef]

14. Bertin, A.; Bortoli, L.C.; Botton, M.; Parra, J.R.P. Host Plant Effects on the Development, Survival, and Reproduction of Dysmicoccus brevipes (Hemiptera: Pseudococcidae) on Grapevines. Ann. Entomol. Soc. Am. 2013, 106, 604-609. [CrossRef]

15. Colasurdo, N.; Gelinas, Y.; Despland, E. Larval nutrition affects life history traits in a capital breeding moth. J. Exp. Biol. 2009, 212, 1794-1800. [CrossRef]

16. Kenis, M.; Auger-Rozenberg, M.-A.; Roques, A.; Timms, L.; Péré, C.; Cock, M.; Settele, J.; Augustin, S.; Lopez-Vaamonde, C. Ecological effects of invasive alien insects. Biol. Invasions 2008, 11, 21-45. [CrossRef]

17. Perrings, C.; Williamson, M.; Barbier, E.B.; Delfino, D.; Dalmazzone, S.; Shogren, J.; Simmons, P.; Watkinson, A. Biological Invasion Risks and the Public Good: An Economic Perspective. Conserv. Ecol. 2002, 6, 1. [CrossRef]

18. Roy, B.A.; Alexander, H.M.; Davidson, J.; Campbell, F.T.; Burdon, J.J.; A Sniezko, R.; Brasier, C. Increasing forest loss worldwide from invasive pests requires new trade regulations. Front. Ecol. Environ. 2014, 12, 457-465. [CrossRef]

19. Schilthuizen, M.; Pimenta, L.P.S.; Lammers, Y.; Steenbergen, P.J.; Flohil, M.; Beveridge, N.G.; van Duijn, P.T.; Meulblok, M.M.; Sosef, N.; van de Ven, R.; et al. Incorporation of an invasive plant into a native insect herbivore food web. PeerJ 2016, 4, e1954. [CrossRef] [PubMed]

20. Łukowski, A.; Janek, W.; Baraniak, E.; Walczak, U.; Karolewski, P. Changing Host Plants Causes Structural Differences in the Parasitoid Complex of the Monophagous Moth Yponomeuta evonymella, but Does Not Improve Survival Rate. Insects 2019, 10, 197. [CrossRef]

21. D'Costa, L.; Koricheva, J.; Straw, N.; Simmonds, M.S. Oviposition patterns and larval damage by the invasive horse-chestnut leaf miner Cameraria ohridellaon different species of Aesculus. Ecol. Entomol. 2013, 38, 456-462. [CrossRef]

22. Rogers, R.; Wallner, C.; Goodwin, B.; Heitland, W.; Weisser, W.; Brosius, H.-B. When do people take action? The importance of people's observation that nature is changing for pro-environmental behavior within the field of impersonal, environmental risk. $J$. Integr. Environ. Sci. 2017, 14, 1-18. [CrossRef]

23. Prestemon, J.P.; Zhu, S.; Turner, J.A.; Buongiorno, J.; Li, R. Forest Product Trade Impacts of an Invasive Species: Modeling Structure and Intervention Trade-Offs. Agric. Resour. Econ. Rev. 2006, 35, 128-143. [CrossRef]

24. Bradshaw, C.J.A.; Leroy, B.; Bellard, C.; Roiz, D.; Albert, C.; Fournier, A.; Barbet-Massin, M.; Salles, J.-M.; Simard, F.; Courchamp, F. Massive yet grossly underestimated global costs of invasive insects. Nat. Commun. 2016, 7, 12986. [CrossRef] [PubMed]

25. Wiatrowska, B.; Łukowski, A.; Karolewski, P.; Danielewicz, W. Invasive Spiraea tomentosa: A new host for monophagous Earias clorana? Arthropod-Plant Interact. 2018, 12, 423-434. [CrossRef]

26. Brockerhoff, E.G.; Liebhold, A.M. Ecology of forest insect invasions. Biol. Invasions 2017, 19, 3141-3159. [CrossRef]

27. Ray, D.; Peace, A.; Moore, R.; Petr, M.; Grieve, Y.; Convery, C.; Ziesche, T. Improved prediction of the climate-driven outbreaks of Dendrolimus pini in Pinus sylvestris forests. Forestry 2016, 89, 230-244. [CrossRef]

28. Kirichenko, N.; Flament, J.; Baranchikov, Y.; Grégoire, J.-C. Larval performances and life cycle completion of the Siberian moth, Dendrolimus sibiricus (Lepidoptera: Lasiocampidae), on potential host plants in Europe: A laboratory study on potted trees. Eur. J. For. Res. 2011, 130, 1067-1074. [CrossRef]

29. Phillips, S.J.; Anderson, R.P.; Schapire, R.E. Maximum entropy modeling of species geographic distributions. Ecol. Model. 2006, 190, 231-259. [CrossRef]

30. Möykkynen, T.; Pukkala, T. Modelling of the spread of a potential invasive pest, the Siberian moth (Dendrolimus sibiricus) in Europe. For. Ecosyst. 2014, 1, 10. [CrossRef]

31. Kanturski, M.; Bugaj-Nawrocka, A.; Wieczorek, K. Pine pest aphids of the genus Eulachnus (Hemiptera: Aphididae: Lachninae): How far can their range extend? Agric. For. Entomol. 2016, 18, 398-408. [CrossRef]

32. Keena, M.A. Survival and Development of Lymantria monacha (Lepidoptera: Lymantriidae) on North American and Introduced Eurasian Tree Species. J. Econ. Entomol. 2003, 96, 43-52. [CrossRef] [PubMed]

33. Skrzecz, I.; Ślusarski, S.; Tkaczyk, M. Integration of science and practice for Dendrolimus pini (L.) management-A review with special reference to Central Europe. For. Ecol. Manag. 2020, 455, 117697. [CrossRef]

34. Le Mellec, A.; Michalzik, B. Impact of a pine lappet (Dendrolimus pini) mass outbreak on C and N fluxes to the forest floor and soil microbial properties in a Scots pine forest in Germany. Can. J. For. Res. 2008, 38, 1829-1841. [CrossRef]

35. Björkman, C.; Lindelöw, Å.; Eklund, K.; Kyrk, S.; Klapwijk, J.; Fedderwitz, F.; Nordlander, G. A rare event-An isolated outbreak of the pine-tree lappet moth (Dendrolimus pini) in the Stockholm archipelago. Entomol. Tidskr. 2013, 134, 1-9.

36. Sukovata, L.; Kolk, A.; Jaroszynska, J.; Krajewska, U.; Purzynska, A.; Isidorov, V. Host-tree preferences of the pine moth (Lepidoptera: Lasiocampidae) and pine beauty moth (Lepidopera: Noctuidae) larvae in relation to needle quality. Ecol. Surv. Manag. For. Insects Proc. 2003, 311, 98-106. 
37. Kolk, A.; Starzyk, J.R. Atlas of Forest Insect Pests; MULTICO Publishing House Ltd.: Warsaw, Poland, 1996.

38. Śliwa, E. Barczatka Sosnówka [Pine-Tree Lappet Moth]; PWRiL: Warsaw, Poland, 1992.

39. Kovač, M.; Lacković, N.; Pernek, M. Effect of Beauveria bassiana Fungal Infection on Survival and Feeding Behavior of Pine-Tree Lappet Moth (Dendrolimus pini L.). Forests 2020, 11, 974. [CrossRef]

40. Matek, M.; Pernek, M. First Record of Dendrolimus pini Outbreak on Aleppo Pine in Croatia and Severe Case of Population Collapse Caused by Entomopathogen Beauveria bassiana. South-East Eur. For. 2018, 9, 91-96. [CrossRef]

41. Keena, M.A.; Shi, J. Effects of Temperature on First Instar Lymantria (Lepidoptera: Erebidae) Survival and Development With and Without Food. Environ. Entomol. 2019, 48, 655-666. [CrossRef]

42. Osier, T.; Jennings, S. Variability in host-plant quality for the larvae of a polyphagous insect folivore in midseason: The impact of light on three deciduous sapling species. Entomol. Exp. Appl. 2007, 123, 159-166. [CrossRef]

43. Milanovic, S.; Lazarević, J.; Popović, Z.; Miletić, Z.; Kostić, M.; Radulović, Z.; Karadžić, D.; Vuleta, A. Preference and performance of the larvae of Lymantria dispar (Lepidoptera: Lymantriidae) on three species of European oaks. Eur. J. Entomol. 2014, 111, 371-378. [CrossRef]

44. Łukowski, A.; Adamczyk, D.; Karolewski, P. Survival and Recovery of the Pine-Tree Lappet Dendrolimus pini When Subjected to Simulated Starvation. Insects 2020, 11, 67. [CrossRef] [PubMed]

45. Elkinton, J.S.; Cardé, R.T. Distribution, Dispersal, and Apparent Survival of Male Gypsy Moths1 as Determined by Capture in Pheromone-Baited Traps2. Environ. Entomol. 1980, 9, 729-737. [CrossRef]

46. Sierpińska, A. Towards an integrated management of Dendrolimus pini L. In Proceedings of the Population Dynamics, Impacts, and Integrated Management of Forest Defoliating Insects; Faculty Publications: Nacogdoches, TX, USA, 1998; Volume 226, pp. 129-142.

47. Sukovata, L. A Comparison of Three Approaches for Larval Instar Separation in Insects-A Case Study of Dendrolimus pini. Insects 2019, 10, 384. [CrossRef] [PubMed]

48. Grodner, J.; Zander, R. Sex propheromone of the pine tree lappet moth Dendrolimus pini and its use in attractant-based monitoring system. Pesticides 2010, 1-4, 43-49.

49. Diaz, J.H. The evolving global epidemiology, syndromic classification, management, and prevention of caterpillar envenoming. Am. J. Trop. Med. Hyg. 2005, 72, 347-357. [CrossRef]

50. Jagiełło, R.; Łakomy, P.; Łukowski, A.; Giertych, M.J. Spreading-the-risk hypothesis may explain Cameraria ohridella oviposition in relation to leaf blotch disease. Arthropod-Plant Interact. 2019, 13, 787-795. [CrossRef]

51. Waldbauer, G. The consumption and utilization of food by insects. Adv. Insect Phys. 1968, 5, 229-288. [CrossRef]

52. Mąderek, E.; Łukowski, A.; Giertych, M.J.; Karolewski, P. Influence of native and alien Prunus species and light conditions on performance of the leaf beetle Gonioctena quinquepunctata. Entomol. Exp. Appl. 2015, 155, 193-205. [CrossRef]

53. Łukowski, A.; Giertych, M.; Zadworny, M.; Mucha, J.; Karolewski, P. Preferential Feeding and Occupation of Sunlit Leaves Favors Defense Response and Development in the Flea Beetle, Altica brevicollis coryletorum-A Pest of Corylus avellana. PLoS ONE 2015, 10, e0126072. [CrossRef]

54. Hansen, J.; Møller, I. Percolation of starch and soluble carbohydrates from plant tissue for quantitative determination with anthrone. Anal. Biochem. 1975, 68, 87-94. [CrossRef]

55. Haissig, B.E.; Dickson, R.E. Starch Measurement in plant tissue using enzymatic hydrolysis. Physiol. Plant. 1979, 47, $151-157$. [CrossRef]

56. Johnson, G.; Schaal, L.A. Accumulation of phenolic substances and ascorbic acid in potato tuber tissue upon injury and their possible role in disease resistance. Am. J. Potato Res. 1957, 34, 200-209. [CrossRef]

57. Singleton, V.L.; Rossi, J.A. Colorimetry of total phenolics with phosphomolybdic-phosphotungstic acid reagents. Am. J. Enol. Vitic. 1965, 16, 144-158.

58. Price, M.L.; Van Scoyoc, S.; Butler, L.G. A critical evaluation of the vanillin reaction as an assay for tannin in sorghum grain. J. Agric. Food Chem. 1978, 26, 1214-1218. [CrossRef]

59. Ghorai, N.; Chakraborty, S.; Gucchait, S.; Saha, S.K.; Biswas, S. Estimation of total terpenoids concentration in plant tissues using a monoterpene, Linalool as standard reagent. Protoc. Exch. 2012, 1-7. [CrossRef]

60. Cornelissen, J.H.C.; Lavorel, S.; Garnier, E.; Díaz, S.; Buchmann, N.; Gurvich, D.E.; Reich, P.; ter Steege, H.; Morgan, H.D.; Van Der Heijden, M.G.A.; et al. A handbook of protocols for standardised and easy measurement of plant functional traits worldwide. Aust. J. Bot. 2003, 51, 335-380. [CrossRef]

61. Garnier, E.; Shipley, B.; Roumet, C.; Laurent, G. A standardized protocol for the determination of specific leaf area and leaf dry matter content. Funct. Ecol. 2001, 15, 688-695. [CrossRef]

62. Bliss, C.I. The transformation of percentages for use in the analysis of variance. Ohio J. Sci. 1938, 38, 9-12.

63. Luo, D.; Lai, M.; Xu, C.; Shi, H.; Liu, X. Life history traits in a capital breeding pine caterpillar: Effect of host species and needle age. BMC Ecol. 2018, 18, 24. [CrossRef] [PubMed]

64. Kirichenko, N.; Baranchikov, Y.N.; Vidal, S. Performance of the potentially invasive Siberian moth Dendrolimus superans sibiricuson coniferous species in Europe. Agric. For. Entomol. 2009, 11, 247-254. [CrossRef]

65. Füldner, K. Entwicklungserfolg von kiefernspinner (Dendrolimus pini Linnaeus, 1758: Lepidoptera, Lasiocampidae) an douglasie (Pseudotsuga menziesii), fichte (Picea abies) und kiefer (Pinus sylvestris) unter laborbedingungen. Allg. Forst. Jagdzeitung 2001, 172, 221-225. 
66. Knolhoff, L.M.; Heckel, D. Behavioral Assays for Studies of Host Plant Choice and Adaptation in Herbivorous Insects. Annu. Rev. Entomol. 2014, 59, 263-278. [CrossRef] [PubMed]

67. Moreau, G.; Quiring, D.T.; Eveleigh, E.S.; Bauce, É. Advantages of a mixed diet: Feeding on several foliar age classes increases the performance of a specialist insect herbivore. Oecologia 2003, 135, 391-399. [CrossRef]

68. Muller, K.; Thiéry, D.; Moret, Y.; Moreau, J. Male larval nutrition affects adult reproductive success in wild European grapevine moth (Lobesia botrana). Behav. Ecol. Sociobiol. 2014, 69, 39-47. [CrossRef]

69. Singer, M.; Bernays, E.; Carrière, Y. The interplay between nutrient balancing and toxin dilution in foraging by a generalist insect herbivore. Anim. Behav. 2002, 64, 629-643. [CrossRef]

70. Mumm, R.; Hilker, M. Direct and indirect chemical defence of pine against folivorous insects. Trends Plant Sci. 2006, 11, 351-358. [CrossRef]

71. Ikeda, T.; Matsumura, F.; Benjamin, D.M. Mechanism of feeding discrimination between matured and juvenile foliage by two species of pine sawflies. J. Chem. Ecol. 1977, 3, 677-694. [CrossRef]

72. Johns, R.C.; Tobita, H.; Hara, H.; Ozaki, K. Adaptive advantages of dietary mixing different-aged foliage within conifers for a generalist defoliator. Ecol. Res. 2015, 30, 793-802. [CrossRef]

73. Beukeboom, L.W. Size matters in insects-An introduction. Entomol. Exp. Appl. 2018, 166, 2-3. [CrossRef]

74. Łukowski, A.; Mąderek, E.; Giertych, M.J.; Karolewski, P. Sex Ratio and Body Mass of Adult Herbivorous Beetles Depend on Time of Occurrence and Light Conditions. PLoS ONE 2015, 10, e0144718. [CrossRef]

75. Lee, K.P.; Roh, C. Temperature-by-nutrient interactions affecting growth rate in an insect ectotherm. Entomol. Exp. Appl. 2010, 136, 151-163. [CrossRef]

76. Kaplan, I.; McArt, S.H.; Thaler, J.S. Plant Defenses and Predation Risk Differentially Shape Patterns of Consumption, Growth, and Digestive Efficiency in a Guild of Leaf-Chewing Insects. PLoS ONE 2014, 9, e93714. [CrossRef] [PubMed]

77. Honěk, A. Intraspecific Variation in Body Size and Fecundity in Insects: A General Relationship. Oikos 1993, 66, 483. [CrossRef]

78. Blanckenhorn, W.U. The evolution of body size: What keeps organisms small? Q. Rev. Biol. 2000, 75, 385-407. [CrossRef]

79. Niinemets, U.; Ellsworth, D.S.; Lukjanova, A.; Tobias, M. Dependence of needle architecture and chemical composition on canopy light availability in three North American Pinus species with contrasting needle length. Tree Physiol. 2002, 22, 747-761. [CrossRef]

80. An, P.-C.; Tang, D.-L.; Chen, H.; Yang, Q.; Ding, S.-T.; Wu, J.-Y. Pliocene white pine (Pinus subgenus Strobus) needles from western Yunnan, southwestern China. Hist. Biol. 2018, 31, 1-11. [CrossRef]

81. Singh, L.; Dixit, P.; Srivastava, R.P.; Pandey, S.; Verma, P.C.; Saxena, G. Morpho-anatomical variation and their phylogenetic implications in native and exotic species of Pinus L. growing in the Indian Himalayas. An. Biol. 2020, 2020, 105-114. [CrossRef]

82. Pelcastre, C.E.; Hernández-León, S.; Gernandt, D.S.; Arce-Cervantes, O.; Rodríguez-Laguna, R.; González-Ávalos, J. Taxonomic identification key with leaf anatomical characters for Pinus L. species in Hidalgo. Rev. Mex. Cienc. For. 2018, 9, 28-49. [CrossRef]

83. Ghimire, B.; Lee, C.; Yang, J.; Heo, K. Comparative leaf anatomy of native and cultivated Pinus (Pinaceae) in Korea: Implication for the subgeneric classification. Plant Syst. Evol. 2015, 301, 531-540. [CrossRef]

84. Karolewski, P.; Giertych, M.J.; Żmuda, M.; Jagodzinski, A.M.; Oleksyn, J. Season and light affect constitutive defenses of understory shrub species against folivorous insects. Acta Oecol. 2013, 53, 19-32. [CrossRef]

85. Hatcher, P.E. Seasonal and age-related variation in the needle quality of five conifer species. Oecologia 1990, 85, 200-212. [CrossRef]

86. Hanley, M.E.; Lamont, B.B.; Fairbanks, M.M.; Rafferty, C.M. Plant structural traits and their role in anti-herbivore defence. Perspect. Plant Ecol. Evol. Syst. 2007, 8, 157-178. [CrossRef]

87. Karolewski, P.; Łukowski, A.; Walczak, U.; Baraniak, E.; Mucha, J.; Giertych, M.J. Larval food affects oviposition preference, female fecundity and offspring survival in Yponomeuta evonymellus. Ecol. Entomol. 2017, 42, 657-667. [CrossRef]

88. Sukovata, L.; Asztemborska, M.; Rudziński, K.J.; Cieślak, M.; Staszek, D.; Janiszewski, W.; Szmigielski, R.; Kolk, A.; Raczko, J. Effect of dispenser type, trap design and placement on catches of pine-tree lappet moth, Dendrolimus pini. Phytoparasitica 2020, 48, 63-74. [CrossRef]

89. Venette, R.C. Exotic Pine Pests: Survey Reference. USDA Forest Service, 2008. Available online: https://www.fs.usda.gov/ Internet/FSE_DOCUMENTS/fsbdev2_026444.pdf (accessed on 30 June 2021).

90. Hernández-Baz, F.; Romo, H.; González, J.M.; Hernández, M.D.J.M.; Pastrana, R.G. Maximum Entropy Niche-Based Modeling (Maxent) of Potential Geographical Distribution of Coreura albicosta (Lepidoptera: Erebidae: Ctenuchina) in Mexico. Fla. Entomol. 2016, 99, 376-380. [CrossRef]

91. Scharf, I. The multifaceted effects of starvation on arthropod behaviour. Anim. Behav. 2016, 119, 37-48. [CrossRef]

92. McCue, M.D. Starvation physiology: Reviewing the different strategies animals use to survive a common challenge. Comp. Biochem. Physiol. Part A Mol. Integr. Physiol. 2010, 156, 1-18. [CrossRef] [PubMed]

93. Gergs, A.; Jager, T. Body size-mediated starvation resistance in an insect predator. J. Anim. Ecol. 2014, 83, 758-768. [CrossRef] 